\title{
Pharmacological Treatment of Advanced, Persistent or Metastatic Endometrial Cancer: State of the Art and Perspectives of Clinical Research for the Special Issue "Diagnosis and Management of Endometrial Cancer"
}

\author{
Angiolo Gadducci *(D) and Stefania Cosio \\ Department of Clinical and Experimental Medicine, Division of Gynecology and Obstetrics, University of Pisa, \\ 56127 Pisa, Italy; stefania.cosio@gmail.com \\ * Correspondence: angiolo.gadducci@unipi.it; Tel.: +39-50992609
}

check for updates

Citation: Gadducci, A.; Cosio, S. Pharmacological Treatment of Advanced, Persistent or Metastatic Endometrial Cancer: State of the Art and Perspectives of Clinical Research for the Special Issue "Diagnosis and Management of Endometrial Cancer". Cancers 2021, 13, 6155. https:// doi.org/10.3390/cancers13246155

Academic Editor: Neville Hacker

Received: 2 November 2021

Accepted: 3 December 2021

Published: 7 December 2021

Publisher's Note: MDPI stays neutral with regard to jurisdictional claims in published maps and institutional affiliations.

Copyright: (c) 2021 by the authors. Licensee MDPI, Basel, Switzerland. This article is an open access article distributed under the terms and conditions of the Creative Commons Attribution (CC BY) license (https:// creativecommons.org/licenses/by/ $4.0 /)$.
Simple Summary: Patients with metastatic or recurrent endometrial cancer (EC) not suitable for surgery and/or radiotherapy are candidates for pharmacological treatment with unsatisfactory clinical outcomes. The combination of carboplatin + paclitaxel is the standard first-line chemotherapy, whereas hormonal therapy is sometimes used in selected patients with slow-growing steroid receptorpositive EC. The combination of endocrine therapy with mTOR inhibitors or cyclin-dependent kinase 4/6 inhibitors is currently under evaluation. Immune checkpoint inhibitors, and especially pembrolizumab and dostarlimab, have achieved an objective response in $27-47 \%$ of highly pretreated patients with microsatellite instability-high/mismatch repair (MMR)-deficient EC.

Abstract: Patients with metastatic or recurrent endometrial cancer (EC) not suitable for surgery and/or radiotherapy are candidates for pharmacological treatment frequently with unsatisfactory clinical outcomes. The purpose of this paper was to review the results obtained with chemotherapy, hormonal therapy, biological agents and immune checkpoint inhibitors in this clinical setting. The combination of carboplatin (CBDCA) + paclitaxel (PTX) is the standard first-line chemotherapy capable of achieving objective response rates (ORRs) of $43-62 \%$, a median progression-free survival (PFS) of 5.3-15 months and a median overall survival (OS) of 13.2-37.0 months, respectively, whereas hormonal therapy is sometimes used in selected patients with slow-growing steroid receptorpositive EC. The combination of endocrine therapy with $\mathrm{m}$-TOR inhibitors or cyclin-dependent kinase 4/6 inhibitors is currently under evaluation. Disappointing ORRs have been associated with epidermal growth factor receptor (EGFR) inhibitors, HER-2 inhibitors and multi-tyrosine kinase inhibitors used as single agents, and clinical trials evaluating the addition of bevacizumab to CBDCA + PTX have reported conflicting results. Immune checkpoint inhibitors, and especially pembrolizumab and dostarlimab, have achieved an objective response in $27-47 \%$ of highly pretreated patients with microsatellite instability-high (MSI-H)/mismatch repair (MMR)-deficient (-d) EC. In a recent study, the combination of lenvatinib + pembrolizumab produced a 24 -week response rate of $38 \%$ in patients with highly pretreated EC, ranging from $64 \%$ in patients with MSI-H/MMR-d to $36 \%$ in those with microsatellite stable/MMR-proficient tumors. Four trials are currently investigating the addition of immune checkpoint inhibitors to PTX + CBDCA in primary advanced or recurrent EC, and two trials are comparing pembrolizumab + lenvatinib versus either CBDCA + PTX as a first-line treatment of advanced or recurrent EC or versus single-agent chemotherapy in advanced, recurrent or metastatic EC after one prior platinum-based chemotherapy.

Keywords: endometrial carcinoma; chemotherapy; hormonal therapy; biological agents; immune checkpoint inhibitors 


\section{Introduction}

GLOBOCAN estimates of the worldwide incidence and mortality for 36 cancers in 185 countries reported 382,069 new cases of endometrial carcinoma (EC) and 89,929 deaths due to this cancer in 2018 [1]. EC has long been subdivided into two main categories termed type I endometrioid carcinoma and type II nonendometrioid carcinoma, but this dualistic model does not take into account the molecular, biological and pathological heterogeneity among each category [2,3]. On the basis of integrated genomic, transcriptomic and proteomic characterization of 373 ECs by array- and sequencing-based technologies, The Cancer Genome Atlas Research Network (TCGA) has proposed a novel classification into four categories termed polymerase $\varepsilon$ (POLE) ultramutated, microsatellite instability (MSI) hypermutated, copy number low (endometrioid) and copy number high (serous-like) [4,5]. Talhouk et al. [6] have suggested a simplified, pragmatic, clinically applicable molecularbased classification system termed Proactive Molecular Risk Classifier for Endometrial Cancer (ProMisE) which does not require the expensive genomic methodology and that is applicable to formalin-fixed paraffin-embedded samples. This system based on mismatch repair (MMR) protein immunohistochemistry, POLE mutational analysis and p53 immunohistochemistry identifies four molecular subtypes that are similar but not identical to genomic TCGA subtypes. This classification has been validated in a large populationbased cohort including $452 \mathrm{ECs}$ from an independent institution [7]. In that study $28.1 \%$ of the tumors were MMR-deficient (MMR-d), 9.3\% were POLE-mutant, $12.2 \%$ were p53abnormal and $50.4 \%$ were p53-wild-type. ProMisE classification significantly correlated with progression-free survival (PFS) and overall survival (OS), with the most and the least favorable outcomes being the POLE-mutant subtype and the p53-abnormal subtype, respectively. The TransPORTEC consortium identified four very similar molecular subtypes using methods easily adopted in laboratories on formalin-fixed paraffin-embedded samples [8,9]. The analysis of 947 available early-stage endometrioid EC specimens from patients enrolled in the PORTEC-1 and PORTEC-2 trials, mostly at high-intermediate risk, revealed that $6 \%$ of the tumors were POLE-mutant, $9 \%$ were p53-mutant, $26 \%$ had MSI, and 59\% had no specific molecular profile (NSMP) [9]. The prognosis was unfavorable in the p53-mutant subset, intermediate in the MSI and NSMP subsets and favorable in the POLE-mutant subset. The feasibility and usefulness of a diagnostic algorithm using immunostaining for p53 and MMR and mutation analysis of POLE have been confirmed in a study of tissue samples from 410 high-risk EC patients enrolled in the PORTEC-3 trial [10]. Twelve percent of the tumors were POLE-mutant, 33\% were MMR-d, 32\% had NSPM and 23\% were p53-abnormal. The corresponding 5-year PFS rates were $98 \%, 72 \%$, $74 \%$ and $48 \%$, respectively $(p<0.001)$. Adjuvant combined chemotherapy and radiotherapy improved the 5-year PFS and 5-year OS compared with adjuvant radiotherapy alone in patients with p53-abnormal tumors $(58.6 \%$ versus $36.2 \%$, hazard ratio $(H R)=0.52,95 \%$ confidence interval $(\mathrm{CI})=0.30-0.91$; and, respectively, $64.9 \%$ versus $41.8 \%, \mathrm{HR}=0.55$, $95 \% \mathrm{CI}=0.30-1.00)$. Conversely, the combined treatment failed to significantly improve the 5-year PFS and 5-year-OS compared with radiotherapy alone in patients with MMR-d EC $(68.0 \%$ versus $75.5 \%, \mathrm{HR}=1.29,95 \% \mathrm{CI}=0.68-2.45$; and, respectively, $78.6 \%$ versus $84.0 \%)$ and in those with NSMP EC $(79.7 \%$ versus $67.7 \%, \mathrm{HR}=0.68,95 \% \mathrm{CI}=0.36-1.3$; and, respectively, $89.3 \%$ versus $87.6 \%, \mathrm{HR}=0.68,95 \% \mathrm{CI}=0.26-1.77)$. It is noteworthy that only one patient with a POLE-mutant EC (treated with radiotherapy alone) relapsed, resulting in a 5-year PFS and 5-year OS of 100\% with combined chemotherapy and radiotherapy versus $96.6 \%$ with radiotherapy alone. Therefore, incorporation of the molecular classification into risk stratification systems is strongly suggested not only for prognostic purposes, but also to better plan adjuvant treatment as recommended by the recent European Society of Gynecological Oncology (ESGO)/European SocieTy for Radiotherapy \& Oncology (ESTRO) and European Society of Pathology (ESP) guidelines [11].

At presentation, most EC patients are in an apparent early stage of disease and undergo primary surgery, usually via a mini-invasive approach, followed by observation or adjuvant treatment according to risk factors [11]. However, $11-19 \%$ of these patients will 
subsequently develop recurrent disease, often involving distant sites [12-17]. A paucity of patients with unresectable, locally advanced EC are treated with definitive radiotherapy or neoadjuvant chemotherapy followed by surgery or definitive radiotherapy $[11,18]$.

Patients with metastatic or recurrent EC that is not suitable for surgery and/or radiotherapy are usually candidates for pharmacological treatments which are frequently associated with unsatisfactory clinical outcomes [19-26]. The aim of this review was to evaluate the results following treatment with chemotherapy, hormone therapy, molecularly targeted agents and immune checkpoint inhibitors and analyze the promising perspectives of research in this clinical setting.

\section{Chemotherapy}

The combination of cisplatin (CDDP) + doxorubicin (DOX) has long been used in advanced or recurrent EC with objective response rates (ORRs) of 34-60\%, median PFS of 5.3-8.0 months and median OS of 9.0-12.3 months, respectively, in chemo-naive patients [19-21]. The Gynecologic Oncology Group (GOG) 177 trial randomly assigned patients with advanced or recurrent disease to receive either DOX + CDDP + paclitaxel (PTX) every 3 weeks (Q3W) (TAP regimen) with granulocyte colony-stimulating factor support or DOX + CDDP Q3W [27]. The three-drug regimen produced higher ORRs $(p<0.01)$, longer PFS (median, $p=0.01$ ) and longer OS (median, $p=0.037$ ), but was associated with higher grade $2-3$ peripheral neuropathy rates (39\% versus $5 \%$ ) [22]. In the GOG 209 randomized trial, the combination of PTX + carboplatin (CBDCA) AQ3W was not inferior to the TAP regimen in terms of PFS $(\mathrm{HR}=1.032,90 \% \mathrm{CI}=0.93-1.15)$ and OS ( $\mathrm{HR}=1.002,90 \% \mathrm{CI}=0.9-1.12)$ [23]. Among the patients with RECIST 1.0 measurable disease, ORR for both arms was $52 \%$. The combination of CBDCA + PTX is the standard first-line chemotherapy for advanced or recurrent EC [11,23-26].

McMeekin et al. [27] performed a pooled analysis of the data from 1203 patients with advanced or recurrent EC who received first-line single-agent or combination regimens, including DOX $(12 \%)$, DOX + CDDP $(63 \%)$, DOX + PTX $(13 \%)$ or TAP $(11 \%)$ within four randomized phase III GOG trials. ORRs were $42 \%$ in the whole series, $44 \%$ in patients with endometrioid carcinoma, $44 \%$ in those with serous carcinoma, $32 \%$ in those with clear cell carcinoma, 37\% in those with mixed carcinomas and 39\% in those with other histological types. In the logistic regression model, histology was not a predictive factor of response, but it was an independent prognostic variable of OS, with an HR of death of $1.2(95 \% \mathrm{CI}=1.02-1.4)$ for serous carcinoma and of $1.51(95 \% \mathrm{CI}=1.1-2.07)$ for clear cell carcinoma compared with all other histologic types.

A multicenter retrospective cohort study assessed 262 patients with recurrent EC who underwent first-line platinum-based chemotherapy and who received second-line platinum-based chemotherapy at the time of relapse [28]. The ORRs for patients with a platinum-free interval (PFI) $<6$ months, 6-11 months, 12-23 months and $\geq 24$ months were $25 \%, 38 \%, 61 \%$ and $65 \%$, respectively. Median PFS after second-line platinum-based chemotherapy was 4.4 months for patients with a PFI $<12$ months versus 10.3 months for those with a PFI $\geq 12$ months $(p<0.0001)$, and the corresponding median OS was 13.8 months versus 40.9 months $(p<0.0001)$. Therefore, the concept of platinum sensitivity is valid for recurrent EC, too.

The chemotherapy options for patients not fit for platinum retreatment are very limited (Table 1). PTX produced ORR of $27-37 \%$ in patients who had received prior chemotherapy not including taxanes [29-31]. In the series of Lissoni et al. [29], this agent achieved a response in $22 \%$ of the nine platinum-resistant patients. Markman et al. [32] reported that weekly PTX $\left(60-80 \mathrm{mg} / \mathrm{m}^{2}\right)$ produced both objective responses and subjective improvement in three patients pretreated with CBDCA + PTX.

The ORRs to the other single agents are unsatisfactory [29-43] (Table 1). 
Table 1. Chemotherapy for metastatic, advanced or recurrent endometrial cancer.

\begin{tabular}{|c|c|c|c|c|c|}
\hline \multicolumn{6}{|c|}{ Platinum-Based Chemotherapy } \\
\hline Study & $\begin{array}{l}\text { Patient } \\
\text { Profile }\end{array}$ & Treatment & ORR & $\begin{array}{l}\text { Outcome (Months) } \\
\text { Median PFS }\end{array}$ & $\begin{array}{l}\text { Outcome (Months) } \\
\text { Median OS }\end{array}$ \\
\hline Trope et al. (1984) [19] & $19^{\mathrm{a}}$ & $50 \mathrm{mg} / \mathrm{m}^{2} \mathrm{DOX}+50 \mathrm{mg} / \mathrm{m}^{2} \mathrm{CDDP}$ q28 & $60 \%$ & NA & NA \\
\hline van Wijk et al. (2003) [20] & $90^{\mathrm{a}}$ & $60 \mathrm{mg} / \mathrm{m}^{2} \mathrm{DOX}+50 \mathrm{mg} / \mathrm{m}^{2} \mathrm{CDDP}$ q28 & $43 \%$ & 8.0 & 9.0 \\
\hline Thigpen et al. (2004) [21] & $131^{\mathrm{a}}$ & $60 \mathrm{mg} / \mathrm{m}^{2} \mathrm{DOX}+50 \mathrm{mg} / \mathrm{m}^{2} \mathrm{CDDP} \mathrm{q} 21$ & $42 \%$ & 5.7 & 9.0 \\
\hline Fleming et al. (2004) [22] & $129^{a}$ & $60 \mathrm{mg} / \mathrm{m}^{2} \mathrm{DOX}+50 \mathrm{mg} / \mathrm{m}^{2} \mathrm{CDDP} \mathrm{q} 21$ & $34 \%$ & 5.3 & 12.3 \\
\hline Fleming et al. (2004) [22] & $134^{\mathrm{a}}$ & $\begin{array}{c}45 \mathrm{mg} / \mathrm{m}^{2} \mathrm{DOX}+50 \mathrm{mg} / \mathrm{m}^{2} \mathrm{CDDP} \mathrm{d} 1 \\
+160 \mathrm{mg} / \mathrm{m}^{2} \mathrm{PTX} \mathrm{d} 21\end{array}$ & $57 \%$ & 8.3 & 15.3 \\
\hline Miller et al. (2020) [23] & $656^{a}$ & $\begin{array}{c}45 \mathrm{mg} / \mathrm{m}^{2} \mathrm{DOX}+50 \mathrm{mg} / \mathrm{m}^{2} \mathrm{CDDP} \mathrm{d} 1 \\
+160 \mathrm{mg} / \mathrm{m}^{2} \mathrm{PTX} \mathrm{d} 2 \mathrm{q} 21\end{array}$ & $52 \%{ }^{\wedge}$ & 13.9 & 41.1 \\
\hline Miller et al. (2020) [23] & $672^{a}$ & CBDCA AUC $6+175 \mathrm{mg} / \mathrm{m}^{2}$ PTX q21 & $52 \%{ }^{\wedge}$ & 13.2 & 37.0 \\
\hline Sovak et al. (2007) [24] & $85^{b *}$ & $\begin{array}{c}\text { CBDCA AUC } 5+175 \mathrm{mg} / \mathrm{m}^{2} \mathrm{PTX} \\
\mathrm{q} 21-28\end{array}$ & $43 \%$ & 5.3 & 13.2 \\
\hline Pectasides et al. (2008) [25] & $47^{\mathrm{a}}$ & CBDCA AUC 6+ PTX 175 mg/m² q21 & $62 \%$ & 15 & 25 \\
\hline Lorusso et al. (2019) [26] & $108^{a}$ & CBDCA AUC $5+175 \mathrm{mg} / \mathrm{m}^{2}$ PTX q21- & $53 \%$ & 10.5 & 29.7 \\
\hline
\end{tabular}

Non-Platinum-Based Chemotherapy

\begin{tabular}{|c|c|c|c|c|c|}
\hline Study & $\begin{array}{l}\text { Patient } \\
\text { Profile }\end{array}$ & Treatment & ORR & $\begin{array}{c}\text { Outcome (Months) } \\
\text { Median PFS }\end{array}$ & $\begin{array}{c}\text { Outcome (Months) } \\
\text { Median OS }\end{array}$ \\
\hline Sutton et al. (1994) [33] & $40^{b}$ & $1.2 \mathrm{~g} / \mathrm{m}^{2}$ IFO d1-4 q28 & $15 \%$ & DOR: 3.9 months & NA \\
\hline Lissoni et al. (1996) [29] & $19^{c}$ & 175 mg/m² PTX q21 & $37 \%$ & NA & NA \\
\hline Lincoln et al. (2003) [30] & $44^{c}$ & $175 \mathrm{mg} / \mathrm{m}^{2}$ PTX q21 & $27 \%$ & DOR: 4.2 months & 10.3 \\
\hline Homesley et al. (2008) [31] & $15^{c}$ & $80 \mathrm{mg} / \mathrm{m}^{2}$ PTX q7 & $27 \%$ & DOR: 16.6 weeks & NA \\
\hline Rose et al. (1996) [34] & $22^{b}$ & $50 \mathrm{mg} / \mathrm{m}^{2}$ oral VP-16 q21 & $0 \%$ & NA & - \\
\hline Muggia et al. (2004) [43] & $42^{b}$ & $50 \mathrm{mg} / \mathrm{m}^{2} \mathrm{PLD} \mathrm{q} 28$ & $9.5 \%$ & & 8.2 \\
\hline Miller et al. (2002) [35] & $22^{b}$ & $0.5-1.5 \mathrm{mg} / \mathrm{m}^{2}$ topotecan $\mathrm{d} 1-5 \mathrm{q} 21$ & $9 \%$ & $\begin{array}{l}\text { DOR for CR: } 6.9 \text { months } \\
\text { DOR for PR: } 2.1 \text { months }\end{array}$ & NA \\
\hline Fracasso et al. (2004) [36] & $52^{b}$ & $130 \mathrm{mg} / \mathrm{m}^{2}$ oxaliplatin q21 & $13 \%$ & DOR: 10.9 months & NA \\
\hline Dizon et al. (2009) [37] & $50^{b}$ & $40 \mathrm{mg} / \mathrm{m}^{2}$ ixabepilone $\mathrm{q} 21$ & $12 \%$ & 2,9 & 8.7 \\
\hline McMeekin et al. (2007) [38] & $248^{b}$ & $40 \mathrm{mg} / \mathrm{m}^{2}$ ixabepilone q21 & $15 \%$ & 3.4 & 10.9 \\
\hline Miller et al. (2009) [39] & $27^{b}$ & $900 \mathrm{mg} / \mathrm{m}^{2}$ pemetrexed q21 & $4 \%$ & 2.7 & 9.4 \\
\hline Tait et al. (2011) [40] & $23^{b}$ & $800 \mathrm{mg} / \mathrm{m}^{2}$ gemcitabine $\mathrm{d} 1,8 \mathrm{q} 21$ & $4 \%$ & 1.7 & NR \\
\hline Makker et al. (2013) [41] & & $60 \mathrm{mg} / \mathrm{m}^{2}$ DOX q21 & $0 \%$ & 2.1 & 5.8 \\
\hline Moreira et al. (2018) [42] & & $60 \mathrm{mg} / \mathrm{m}^{2}$ DOX q21 & $12 \%$ & 4.4 & 8.1 \\
\hline
\end{tabular}

${ }^{a}$ No prior chemotherapy. ${ }^{b}$ Prior chemotherapy. ${ }^{b *}$ Prior chemotherapy in $13(15 \%)$ patients. ${ }^{c}$ Prior chemotherapy not including PTX. `Among patients with RECIST 1.0 measurable disease. Legend: Pts, patients; RR, response rate; PFS, progression-free survival; OS, overall survival; DOX, doxorubicin; CDDP, cisplatin; NA, not available; PTX, paclitaxel; AUC, area under the curve; IFO, ifosfamide; DOR, duration of response; PTX, paclitaxel; VP-16, etoposide; PLD, pegylated liposomal doxorubicin; NR, not reached.

For example, DOX achieved ORR ranging from $0 \%$ to $12 \%$ in patients who progressed after PTX + CBDCA [41,42].

A phase III trial randomly allocated 496 patients with advanced, recurrent or metastatic EC who failed prior platinum-based chemotherapy to receive either ixabepilone or either PTX or DOX Q3W [38]. Patients previously treated with an anthracycline were randomized to either ixabepilone or PTX. The study was stopped early because the interim analysis of futility for OS favored the control arm $(\mathrm{HR}=1.3,95 \% \mathrm{CI}=1.0-1.7)$.

\section{Hormonal Therapy}

Progestins, such as medroxyprogesterone acetate (MPA), megestrol acetate (MA) or hydroxyprogesterone caproate, produced objective responses in $11-25 \%$ of patients, with no significant advantage for any one agent [44-47] (Table 2).

The highest chances of response were observed in patients with well-differentiated tumor grade and positive progesterone receptor (PR) status. In a GOG randomized trial, 
$1000 \mathrm{mg}$ /daily MPA did not improve ORR or clinical outcome of patients compared with $200 \mathrm{mg} /$ daily MPA [46].

Tamoxifen (TAM), which itself has a modest activity [48], could increase PR expression in cancer tissues and enhance the effectiveness of progestins in EC [49]. However, clinical studies on alternating treatment with TAM and progestins have given uncertain and unsatisfactory results [47,50,51]. For instance, in the study of Fiorica et al. [51], $80 \mathrm{mg}$ MA twice daily (BID) for 3 weeks alternating with $20 \mathrm{mg}$ TAM BID for 3 weeks achieved ORR of $31 \%$ in patients with extrapelvic disease compared to $14 \%$ in those with pelvic and/or vaginal disease.

Table 2. Endocrine therapy for metastatic, advanced or recurrent endometrial cancer.

\begin{tabular}{|c|c|c|c|c|c|}
\hline Study & $\begin{array}{l}\text { Patient } \\
\text { Profile }\end{array}$ & Treatment & ORR & $\begin{array}{l}\text { Outcome (Months) } \\
\text { Median PFS }\end{array}$ & $\begin{array}{l}\text { Outcome (Months) } \\
\text { Median OS }\end{array}$ \\
\hline Piver (1980) [44] & $114^{\mathrm{a}}$ & \multirow{2}{*}{$\begin{array}{l}\text { Different progestins (MAP, OH-P-caproate) } \\
\text { Different progestins (MAP, OH-P-caproate, } \\
\text { medrogestone) }\end{array}$} & $16 \%$ & NA & 47.9 for $\mathrm{OR}$ \\
\hline Podratz (1985) [45] & 155 & & $37 \%$ & NA & $\begin{array}{c}1 \text { year: } 40 \% \text {; } 2 \text { years: } \\
19 \% \text {; } 5 \text { years: } 8 \%\end{array}$ \\
\hline \multirow{2}{*}{ Thigpen (1999) [46] } & $145^{\mathrm{a}}$ & MPA, $200 \mathrm{mg}$ & $25 \%$ & 3 & 11 \\
\hline & $154^{\mathrm{a}}$ & MPA, $1000 \mathrm{mg}$ & $16 \%$ & 2 & 7 \\
\hline \multirow{2}{*}{ Pandya (2001) [47] } & $20^{\mathrm{a}}$ & MA, $80 \mathrm{mg}$ BID & $20 \%$ & NA & 12 \\
\hline & $21^{\mathrm{a}}$ & $80 \mathrm{mg}$ MA + $10 \mathrm{mg}$ TAM BID & $19 \%$ & NA & 9 \\
\hline Thigpen (2001) [48] & $68^{\mathrm{a}}$ & TAM, $20 \mathrm{mg}$ & $10 \%$ & 2 & 9 \\
\hline Whitney (2004) [50] & $58^{a}$ & MAP, 200 mg / TAM, 40 mg & $33 \%$ & 3 & 13 \\
\hline Fiorica (2004) [51] & $56^{\mathrm{a}}$ & MA, $80 \mathrm{mg} / \mathrm{TAM}, 20 \mathrm{mg}$ BID q21 & $27 \%$ & 3 & 14 \\
\hline Rose (2000) [52] & $23^{b}$ & Anastrozole, $1 \mathrm{mg}$ & $9 \%$ & 1 & 6 \\
\hline Ma (2004) [53] & $\begin{array}{l}28^{b} \\
53^{c}\end{array}$ & Letrozole, $2.5 \mathrm{mg}$ & $9 \%$ & NA & NA \\
\hline Covens (2011) [54] & $\begin{array}{l}22 \mathrm{RE}- \\
31 \mathrm{RE}+\end{array}$ & Fulvestrant, 250 mg q28 & $\begin{array}{c}0 \% \\
16 \%\end{array}$ & $\begin{array}{c}2 \\
10\end{array}$ & $\begin{array}{c}3 \\
26\end{array}$ \\
\hline Emons (2013) [55] & $35 \mathrm{~d}, \hat{\imath}$ & Fulvestrant, 250 mg q28 & $11 \%$ & 2 & 13 \\
\hline
\end{tabular}

${ }^{a}$ No prior systemic therapy. ${ }^{b}$ No more than one prior hormonal therapy and no prior chemotherapy. ${ }^{c}$ Prior hormonal therapy and/or prior chemotherapy. ${ }^{\mathrm{d}}$ No prior hormonal therapy; prior chemotherapy in 14 pts; ${ }^{\wedge} \mathrm{RE}+$ and/or PR+. Legend: Pts, patients; RR, response rate; PFS, progression-free survival; OS, overall survival; MPA, medroxyprogesterone acetate; $\mathrm{OH}-\mathrm{P}, 17 \alpha$ hydroxyprogesterone; medrogestone, 6,17 $\alpha$-dimethyl-6-dehydroprogesterone; MA, megestrol acetate; BID, bis in day.

Aromatase inhibitors and fulvestrant have limited efficacy [52-55].

Cyclin-dependent kinase 4/6 inhibitors have shown antineoplastic activity both in vitro against human EC cell lines and in vivo in xenograft models of EC [56,57]. In phase II trial NCT02657928, 55\% of the 20 patients with recurrent estrogen receptor (ER)positive EC were alive and progression-free at 12 weeks following treatment with ribociclib ( $400 \mathrm{mg}$ orally daily) + letrozole ( $2.5 \mathrm{mg}$ orally daily) [58]. Other trials are currently assessing the combination of cyclin-dependent kinase 4/6 inhibitors and hormonal agents in this clinical setting. The NCT02730429 study (ENGOT-EN3-NSGO/PALEO) is a randomized double-blind placebo-controlled phase II trial of palbociclib + letrozole versus placebo + letrozole in patients with ER-positive, advanced or recurrent EC [59]. NCT03643510 is a phase II study of fulvestrant + abemaciclib in hormone receptor-positive EC.

\section{4. mTOR Inhibitors}

The phosphatidylinositol 3-kinase (PI3K)/Akt/mammalian target of rapamycin (mTOR) pathway is often activated in EC, making it an attractive target for biological agents. However, ORRs to mTOR inhibitors are disappointing [60-65] (Table 3). 
Table 3. mTOR inhibitors for metastatic, advanced or recurrent endometrial cancer.

\begin{tabular}{|c|c|c|c|c|c|c|}
\hline Study & $\begin{array}{l}\text { Patient } \\
\text { Profile }\end{array}$ & Treatment & Pts & ORR & $\begin{array}{c}\text { Outcome } \\
\text { (Months) } \\
\text { Median PFS }\end{array}$ & $\begin{array}{c}\text { Outcome } \\
\text { (Months) } \\
\text { Median OS }\end{array}$ \\
\hline Ray-Coquard et al. (2010) [60] & $44^{\mathrm{a}}$ & Everolimus, $10 \mathrm{mg}$ & $44^{\mathrm{a}}$ & $4 \%$ & 3 & 8 \\
\hline Slomovitz et al. (2015) [66] & $35^{\mathrm{a}}$ & $2.5 \mathrm{mg}$ letrozole $+10 \mathrm{mg}$ everolimus & $35^{a}$ & $31 \%$ & 3 & 14 \\
\hline Soliman et al. (2015) [67] & $54^{\mathrm{a}}$ & $\begin{array}{c}500 \mathrm{mg} \text { metformin }+2.5 \mathrm{mg} \text { letrozole }+ \\
10 \mathrm{mg} \text { everolimus BID }\end{array}$ & $54^{\mathrm{a}}$ & $28 \%$ & 6 & 20 \\
\hline \multirow{2}{*}{ Oza et al. (2011) [64] } & $29^{b}$ & Temsirolimus, 25 mg weekly & $29^{b}$ & $14 \%$ & 7 & NA \\
\hline & $25^{\mathrm{a}}$ & Temsirolimus, 25 mg weekly & $25^{\mathrm{a}}$ & $4 \%$ & 3 & NA \\
\hline \multirow{6}{*}{ Fleming et al. (2014) [65] } & $11^{c}$ & $25 \mathrm{mg}$ temsirolimus weekly $+80 \mathrm{mg}$ & $11^{\mathrm{c}}$ & $9 \%$ & $5^{\wedge}$ & $11^{\wedge}$ \\
\hline & $10^{\mathrm{d}}$ & TAM BID / 20 mg TAM BID for 3 & $10^{\mathrm{d}}$ & $20 \%$ & $8^{\wedge}$ & $21^{\wedge}$ \\
\hline & 21 & weeks & 21 & $14 \%$ & & \\
\hline & $29^{c}$ & & $29^{c}$ & $24 \%$ & & \\
\hline & $21^{\mathrm{d}}$ & Temsirolimus, 25 mg weekly & $21^{d}$ & $19 \%$ & & \\
\hline & 50 & & 50 & $11 \%$ & & \\
\hline Colombo et al. (2013) [61] & $45^{\mathrm{a}}$ & Ridaforolimus, 12.5 mg d1-5 q15 & $45^{\mathrm{a}}$ & $11 \%$ & 6-PFS: $18 \%$ & NA \\
\hline \multirow{3}{*}{ Oza et al. (2015) [63] } & $48^{c}$ & Ridaforolimus, 40 mg d1-5/week & $48^{c}$ & $0 \%$ & 6 & 10 \\
\hline & $47^{c}$ & Comparator * & $47^{\mathrm{c}}$ & $4 \%$ & 2 & 10 \\
\hline & $34^{\mathrm{e}}$ & & $34^{\mathrm{e}}$ & $9 \%$ & & \\
\hline \multirow[t]{2}{*}{ Tsoref et al. (2014) [62] } & $11^{\mathrm{a}}$ & Ridaforolimus, 40 mg q1-5 q15 & $11^{\mathrm{a}}$ & $9 \%$ & NA & NA \\
\hline & $23^{b}$ & & $23^{b}$ & $9 \%$ & & \\
\hline \multirow[t]{2}{*}{ Heudel et al. (2021) [68] } & $49^{a, \S}$ & $\begin{array}{c}125 \mathrm{mg} \text { vistusertib BID + } 1 \mathrm{mg} \\
\text { anastrozole }\end{array}$ & $49^{a}, \S$ & $24 \%$ & PFS-8w: $67 \%$ & PFS: 5 \\
\hline & $24^{\mathrm{a}, \S}$ & Anastrozole, $1 \mathrm{mg}$ & $24^{a, \S}$ & $17 \%$ & PFS-8w: 39\% & 2 \\
\hline
\end{tabular}

`Both arms combined. * MPA, MA, CBDCA, PTX, topotecan, DOX or PLD. ${ }^{\S}$ ER/PR positive. ${ }^{\text {a }}$ Prior chemotherapy. ${ }^{b}$ No prior chemotherapy; prior hormonal therapy. ${ }^{c}$ Prior chemotherapy, no hormonal therapy. ${ }^{d}$ No prior chemotherapy, no hormonal therapy. e Prior hormonal therapy; prior chemotherapy only permitted on adjuvant setting. Legend: Pts, patients; RR, response rate; PFS, progression-free survival; OS, overall survival; MA, megestrol acetate; TAM, tamoxifen; MPA, MPA, medroxyprogesterone acetate; CBDCA, carboplatin; PTX, paclitaxel; PLD, pegylated liposomal doxorubicin.

In a phase II study, temsirolimus produced a response in $14 \%$ of chemo-naive patients and in $4 \%$ of those who had received prior chemotherapy [64]. Histological type, tumor grade, PTEN loss and the expression of molecular markers of the PI3K/Akt/mTOR pathway (mTOR, phosphorylated AKT (pAKT) and phosphorylated S6 (pS6)) did not correlate with the clinical outcome. In another study, ORRs to temsirolimus were similar in chemo-naive patients and in patients with prior chemotherapy [65].

Since the PI3K/AKT/mTOR pathway activation may lead to resistance to endocrine therapy, the combination of mTOR inhibitors and hormonal agents has been tested in EC. Letrozole + everolimus achieved an objective response in $31 \%$ and a clinical benefit in $40 \%$ of heavily pretreated patients [66]. No response was detected in patients with serous carcinoma, whereas patients with endometrioid histology and CTNNB1 mutations had the greatest clinical benefit from this treatment. The combination of metformin + letrozole + everolimus produced an objective response and a stable disease in $28 \%$ and $22 \%$ of the patients, respectively [67].

The NCT03008408 trial is a phase II randomized two-arm study of everolimus + letrozole with or without ribociclib in patients with advanced or recurrent EC.

In the VICTORIA phase I-II study, patients with recurrent ER- and/or PR-positive advanced/metastatic EC were randomized (2:1) to either the target of rapamycin complex (mTORC) 1 and mTORC2 inhibitor vistusertib + anastrozole or single-agent anastrozole [68]. The combination arm showed a meaningful improvement in the 8-week PFS and median PFS compared with single-agent anastrozole $(67 \%$ versus $39 \%$, and 5.2 months versus 1.9 months, respectively) with acceptable toxicity. Fatigue, lymphopenia, hyperglycemia and diarrhea were the main vistusertib-related grade $\geq 2$ adverse events (AE). 


\section{EGFR Inhibitors, HER-2 Inhibitors, MEK Inhibitors and MET Inhibitors}

Gefitinib, erlotinib, lapatinib and trastuzumab have no meaningful activity [69-72] (Table 4).

For example, erlotinib produced a response lasting 2-36 months in 12\% of patients who had received one line of prior hormonal therapy and no chemotherapy [69]. Molecular analysis did not identify epidermal growth factor receptor (EGFR) mutations in responders. Trastuzumab produced no objective response in patients with HER2-positive EC after prior chemotherapy [71]. Conversely, in a phase II trial including 61 patients with HER2-positive serous carcinomas, the addition of trastuzumab (initial dose of $8 \mathrm{mg} / \mathrm{kg}$ IV, then $6 \mathrm{mg} / \mathrm{kg}$ ) to CBDCA (area under the curve (AUC5)) $+175 \mathrm{mg} / \mathrm{m}^{2}$ PTX Q3W improved the median PFS in the whole series (12.6 versus 8.0 months, $\mathrm{HR}=0.44 ; 90 \% \mathrm{CI}=0.26-0.76$ ), in patients with stage III-IV disease (17.9 versus 9.3 months, $\mathrm{HR}=0.40,90 \% \mathrm{CI}=0.20-0.80$ ) and in patients with recurrent disease (9.2 versus 6.0 months, $\mathrm{HR}=0.14 ; 90 \% \mathrm{CI}=0.05-0.54)$ [73].

Table 4. EGFR inhibitors, Her-2 inhibitors, MEK inhibitor and MET inhibitor in metastatic, advanced or recurrent endometrial cancer.

\begin{tabular}{|c|c|c|c|c|c|}
\hline Study & $\begin{array}{l}\text { Patient } \\
\text { Profile }\end{array}$ & Treatment & ORR & $\begin{array}{l}\text { Outcome (Months) } \\
\text { Median PFS }\end{array}$ & $\begin{array}{l}\text { Outcome (Months) } \\
\text { Median OS }\end{array}$ \\
\hline Oza et al. (2008) [69] & $32^{a}$ & Erlotinib, $150 \mathrm{mg}$ & $12 \%$ & NA & NA \\
\hline Leslie et al. (2013) [70] & $26^{\mathrm{b}}$ & Gefitinib, $500 \mathrm{mg}$ & $4 \%$ & 1.8 & 7.1 \\
\hline Leslie et al. (2012) [72] & $30^{b}$ & Lapatinib, $1500 \mathrm{mg}$ & $3 \%$ & 1.8 & 7.3 \\
\hline Fleming et al. (2010) [71] & $33^{c \wedge}$ & $4 \mathrm{mg} / \mathrm{kg}$ trastuzumab, then $2 \mathrm{mg} / \mathrm{kg}$ weekly & $0 \%$ & $\begin{array}{l}1.81^{*} \\
1.8^{* *}\end{array}$ & $\begin{array}{c}6.8^{*} \\
7.8^{* *}\end{array}$ \\
\hline Ali-Ahmad et al. (2021) [74] & $28^{d}$ & $\begin{array}{c}8 \mathrm{mg} / \mathrm{kg} \text { trastuzumab, then } 6 \mathrm{mg} / \mathrm{kg}+840 \\
\mathrm{mg} \text { pertuzumab, then } 420 \mathrm{mg}\end{array}$ & $7 \%$ & 28 weeks & NA \\
\hline Coleman et al. (2015) [75] & $52^{b}$ & Selumetinib, 75 mg BID & $6 \%$ & 2 & 8 \\
\hline \multirow{3}{*}{ Dhani et al. (2020) [76] } & $\mathrm{E} 36^{\mathrm{b}}$ & & $14 \%$ & 5 & NR \\
\hline & $\mathrm{S} 34^{\mathrm{b}}$ & & $12 \%$ & 4 & NR \\
\hline & $\mathrm{UH} 32^{\mathrm{b}}$ & Cabozantinib, $60 \mathrm{mg}$ & $6 \%$ & 3 & NR \\
\hline
\end{tabular}

HER-amplified. * HER amplification by FISH/immunohistochemistry-positive. ${ }^{* *}$ Immunohistochemistry-positive (HER2+, 3+). ${ }^{\text {a }}$ Prior hormonal therapy; no chemotherapy. ${ }^{\mathrm{b}}$ Prior chemotherapy. ${ }^{\mathrm{c}}$ Prior chemotherapy regimens (total prior doxorubicin dose limited to $\left.320 \mathrm{mg} / \mathrm{m}^{2}\right) .{ }^{\mathrm{d}}$ ERBB2 amplification or overexpression $(n=22)$; ERBB2 mutations $(n=4)$; ERBB3 $(n=1)$; both ERBB2 amplification and mutation (No. 1). Legend: Pts, patients; RR, response rate; PFS, progression-free survival; OS, overall survival; NA, not available; E, endometroid; S, serous; UH, uncommon histology.

In the phase II basket TAPUR study, the combination of pertuzumab + trastuzumab Q3W obtained ORR of 7\%, median PFS of 28 weeks in a cohort of EC patients with ERBB2 or ERBB3 amplified, overexpressing or mutated tumors [74]. One patient developed grade 3 muscle weakness, whereas there were no additional G3-4 AEs.

The MEK-1/2 inhibitor selumetinib achieved a response in 6\% and 6-month PFS in $12 \%$ of heavily pretreated patients [75] (Table 4 ). The drug failed to meet the prespecified efficacy parameters for ORR (10\%) and percentage of patients with 6-month PFS (15\%).

The MET inhibitor cabozantinib produced ORR of $14 \%, 12 \%$ and $6 \%$, respectively, in patients with endometrioid, serous and uncommon histology [76]. A higher frequency of response was observed in patients with somatic CTNNB1 mutation and in those with concurrent somatic KRAS and PTEN or PIK3CA mutations (ORR of $40 \%$ and $25 \%$, respectively).

\section{Antiangiogenic Agents}

The treatment of EC patients with multitarget tyrosine kinase inhibitors sorafenib, sunitinib, nintedanib and lenvatinib achieved disappointing results [77-86] (Table 5).

For example, the single-agent lenvatinib targeting vascular endothelial growth factor (VEGF) receptor (VEGFR) 1-3, fibroblast growth factor receptor (FGFR) 1-4, plateletderived growth factor receptor (PDGFR), RET and KIT produced ORR of 14\% [81]. The most common AEs of any grade were fatigue/asthenia, hypertension, nausea/vomiting, decreased appetite and diarrhea. 
Trebananib is a peptide $\mathrm{F}_{\mathrm{C}}$ fusion protein that binds angiopoetin- 1 and -2 , prevents their interaction with Tie2 receptors on endothelial cells and induces vascular remodeling antiangiogenetic activity in preclinical models of EC [83]. Trebananib obtained ORR of 3\% and a 6-month PFS rate of $19 \%$ [84]. The most common toxicities of any grade were fatigue, anemia, constipation, hypertension, nausea, abdominal pain and limb edema.

Table 5. Antiangiogenic agents in metastatic, advanced or recurrent endometrial cancer.

\begin{tabular}{|c|c|c|c|c|c|}
\hline Study & Patient Profiles & Treatment & ORR & $\begin{array}{l}\text { Outcome (Months) } \\
\text { Median PFS }\end{array}$ & $\begin{array}{c}\text { Outcome (Months) } \\
\text { Median OS }\end{array}$ \\
\hline \multirow{2}{*}{ Nimeiri et al. (2010) [77] } & Carcinoma $40^{\mathrm{a}}$ & Sorafenib, $400 \mathrm{mg}$ BID & $5 \%$ & 3 & 11 \\
\hline & Carcinosarcoma $16^{\mathrm{a}}$ & & $0 \%$ & 2 & 5 \\
\hline Castonguay et al. (2014) [78] & $33^{a}$ & Sunitinib, $50 \mathrm{mg}$ & $18 \%$ & 3 & 19 \\
\hline Dizon et al. (2014) [79] & $32^{\mathrm{a}}$ & Nintedanib, 200 mg BID & $9 \%$ & 3 & 10 \\
\hline Bender et al. (2015) [80] & $48^{\mathrm{a}}$ & Cediranib, $30 \mathrm{mg}$ & $12 \%$ & 4 & 12 \\
\hline Vergote et al. (2020) [81] & $133^{a}$ & Lenvatinib, $24 \mathrm{mg}$ & $14 \%$ & 6 & 11 \\
\hline Moore et al. (2015) [84] & $32^{a}$ & Trebananib, $15 \mathrm{mg} / \mathrm{kg}$ & $3 \%$ & 2 & 7 \\
\hline Coleman et al. (2012) [85] & $44^{\mathrm{a}}$ & Aflibercept, $4 \mathrm{mg} / \mathrm{kg}$ & $7 \%$ & 3 & 14 \\
\hline Aghajanian et al. (2011) [86] & $52^{\mathrm{a}}$ & Bevacizumab, $15 \mathrm{mg} / \mathrm{kg}$ & $13 \%$ & 4 & 10 \\
\hline
\end{tabular}

${ }^{a}$ Prior chemotherapy. Legend: Pts, patients; RR, response rate; PFS, progression-free survival; OS, overall survival.

Aflibercept, a novel VEGF ligand-binding fusion protein that serves as a "decoy receptor" for VEGF, achieved ORR of $7 \%$ and a 6-month PFS rate of $41 \%$ [85] (Table 5). Grade $>3$ AEs were cardiovascular, constitutional, hemorrhage, metabolic and pain. Two treatment-related deaths occurred due to gastrointestinal perforation and arterial rupture, respectively.

In a GOG phase II trial assessing single-agent BEV in recurrent or persistent EC, only $13 \%$ of patients experienced an objective response with a median response duration of 6 months [86]. The percentage of patients who had 6-month PFS was 35\% for endometrioid carcinoma and $36 \%$ for serous carcinoma. Neither gastrointestinal perforation/fistula nor treatment-related death occurred.

The NRG Oncology/GOG-86P phase II trial randomly assigned 349 chemo-naive patients with stage III/IVA EC and measurable disease, stage IVB EC or recurrent EC to receive (i) CBDCA (AUC 5-6) + PTX (135-175 mg/m²) for six cycles with concurrent and maintenance BEV (15 mg/ $\mathrm{kg}$ ) Q3W or (ii) CBDCA (AUC 5) + PTX (135-175 mg/m²) for six cycles with concurrent temsirolimus ( $25 \mathrm{mg}$ IV on days 1 and 8 ) and maintenance temsirolimus (25 mg IV on days 1 and 15) Q3W or (iii) ixabepilone $\left(25-30 \mathrm{mg} / \mathrm{m}^{2}\right)+$ CBDCA (AUC 5-6) with concurrent and maintenance BEV (15 mg/kg) Q3W [87]. The corresponding ORRs were $60 \%, 55 \%$ and $53 \%$, respectively. PFS was not significantly increased in any experimental arm compared with historical controls represented by the patients of the CBDCA + PTX arm of the GOG 209 trial (23). Conversely, OS was improved in CBDCA + PTX + BEV arm ( $\mathrm{HR}=0.71,92 \% \mathrm{CI}=0.55-0.91)$ but not in the other two arms, compared with historical controls. A subset analysis showed that combining chemotherapy with BEV could enhance both PFS and OS in patients with p53-mutant EC, which suggested that more aggressive tumors might draw a major benefit from angiogenesis inhibition [88].

In the MITO END-2 phase II randomized trial, the addition of concomitant and maintenance BEV (15 mg/ $\mathrm{kg})$ to CBDCA (AUC 5) + PTX $\left(175 \mathrm{mg} / \mathrm{m}^{2}\right)$ Q3W failed to significantly improve PFS (median, 13.7 versus 10.5 months, $\mathrm{HR}=0.84,95 \% \mathrm{CI}=0.5-1.3$ ) and OS (median, 40.0 versus 29.7 months, $\mathrm{HR}=0.71,95 \% \mathrm{CI}=0.31-1.36$ ) compared with chemotherapy alone in 108 patients with stage III-IV or recurrent EC [26].

\section{Immune Checkpoint Inhibitors}

Programmed death (PDO-1) inhibitors and PD-ligand (PD-L1) inhibitors are novel, very promising therapeutic tools [89-98] (Table 6). 
Table 6. Immune checkpoint inhibitors in metastatic, advanced or recurrent endometrial cancer.

\begin{tabular}{|c|c|c|c|c|c|}
\hline Study & Patient Profile & Treatment & ORR & $\begin{array}{l}\text { Outcome (Months) } \\
\text { Median PFS }\end{array}$ & $\begin{array}{l}\text { Outcome (Months) } \\
\text { Median OS }\end{array}$ \\
\hline Ott et al. (2017) [90] & $24^{\text {a }}$ PD-L1+ & Pembrolizumab, $10 \mathrm{mg} / \mathrm{kg}$ & $12 \%$ & 2 & NR \\
\hline \multirow{2}{*}{$\begin{array}{c}\text { Kostantinoupoulos et al. } \\
\text { (2019) [93] }\end{array}$} & $16^{\mathrm{a}} \mathrm{MMRp}$ & \multirow[b]{2}{*}{ Avelumab, 10 mg/kg } & $6 \%$ & 2 & 7 \\
\hline & $15^{\mathrm{a}}$ MMRd & & $27 \%$ & 4 & NR \\
\hline Oaknin et al. (2020) [95] & $71^{\mathrm{a}} \mathrm{MMRd}$ & Dostarlimab, $500 \mathrm{mg}$ & $42 \%$ & 8 & NR \\
\hline Liu et al. (2019) [96] & $15^{\mathrm{a}, \mathrm{b}}$ PD-L1+ & Atezolizumab, 1200 mg q21 & $13 \%$ & 1 & 10 \\
\hline \multirow{2}{*}{ Antillet al. (2021) [97] } & $35^{\mathrm{a}}$ MMRd & \multirow{2}{*}{ Durvalumab, $1500 \mathrm{mg}$} & $47 \%$ & 8 & NR \\
\hline & $36^{\mathrm{a}} \mathrm{MMRp}$ & & $3 \%$ & 2 & 12 \\
\hline Azad et al. (2020) [98] & $13^{\mathrm{a}} \mathrm{MMRd}$ & Nivolumab, $3 \mathrm{mg} / \mathrm{kg}$ & $46 \%$ & NA & NA \\
\hline \multirow{2}{*}{ Lheureux et al. (2020) [99] } & 18 & Nivolumab, $240 \mathrm{mg}$ & $17 \%$ & 2 & NA \\
\hline & $36^{\mathrm{a}}$ & $\begin{array}{l}240 \mathrm{mg} \text { nivolumab }+40 \mathrm{mg} \\
\text { cabozantinib }\end{array}$ & $25 \%$ & 5 & NA \\
\hline \multirow{2}{*}{ Makke et al. (2020) [100] } & $94^{\mathrm{a}} \mathrm{MSS} / \mathrm{MMRp}$ & $20 \mathrm{mg}$ lenvatinib $+200 \mathrm{mg}$ & $36 \%$ & 4 & \multirow[t]{2}{*}{ NR } \\
\hline & $11^{\mathrm{a}} \mathrm{MSH}-\mathrm{I} / \mathrm{MMRd}$ & pembrolizumab & $64 \%$ & 19 & \\
\hline
\end{tabular}

a Stratification for MSI status; b MSS (No. 12), MSI-H (No. 1), MSI status unknown (No. 2). Legend: Pts, patients; RR, response rate; PFS, progression-free survival; OS, overall survival; PD-L1, programmed death ligand; MSS, microsatellite stability; NR, not reached; MMRp, mismatch repair-proficient; MSI-H, microsatellite instability-high; MMRd, mismatch repair-deficient.

The PD-1 inhibitor pembrolizumab (200 $\mathrm{mg}$ IV Q3W) produced ORR of 34\% in 233 patients with previously treated, advanced, unresectable or metastatic MSI-H/MMR-d non-colorectal cancers of different types enrolled in the GOG 158 trial [89]. It is noteworthy that $70 \%$ of the 47 patients with EC experienced a $\geq 30 \%$ reduction in tumor size.

Pembrolizumab (10 mg/kg IV Q2W) resulted in an objective response in three (12\%) and a stable disease in additional three (12\%) of the 24 patients with heavily pretreated, advanced or metastatic PD-L1-positive EC included in the KEYNOTE-028 study [90]. The median duration of response was not yet reached, whereas the median duration of stable disease was 24.6 weeks. Twelve-month PFS and 12-month OS were 14.3\% and 51.0\%, respectively. All the three responders had endometrioid carcinoma, and one of them had a POLE mutation. This mutation was associated with high tumor mutational burden (TMB) and elevated expression of several immune checkpoint genes [91].

The cumulative analysis of 149 patients with MSI-H/MMR-d cancers of 15 different types enrolled in five clinical trials found that pembrolizumab produced ORR of $40 \%$, with $78 \%$ of responses lasting $\geq 6$ months [92].

The PD-L1 inhibitor avelumab (10 $\mathrm{mg} / \mathrm{kg}$ IV Q2W) produced an objective response in $27 \%$ of patients with MMR-d EC. PD-L1 expression, number of tumor-infiltrating lymphocytes and TMB did not correlate with the response [93]. Three of the tumors not responding to avelumab harbored mutations of Janus kinase 1 or beta-2 microglobulin, which have been associated with acquired resistance to immune checkpoint inhibitors in melanoma [94]. Conversely, avelumab had no meaningful activity in MMR-proficient (MMR-p) ECs.

In the Garnet trial, the anti-PD1 dostarlimab (500 mg IV Q3W for four doses, then $1000 \mathrm{mg}$ Q6W) resulted in a complete response in nine and a partial response in 21 of the 71 patients with MMR-d EC, with ORR of $42 \%$ ranging from $40 \%$ in type I EC to $48 \%$ in type II EC [95]. The median duration of response was not reached after a median follow-up of 11.2 months, and $77 \%$ of patients were alive at 12 months. The most common G3 AEs were anemia, colitis and diarrhea.

The anti PD-L1 durvalumab (1500 mg IV Q4W) produced ORR of 47\% in women with MMR-d EC progressing after 0-3 lines of chemotherapy and 3\% in those with MMRp EC progressing after 1-3 chemotherapy regimens [97]. AEs occurred in 20\% of the patients and mainly consisted of G1-2 hypothyroidism, hyperthyroidism, pneumonitis and hypoadrenalism. Only one case of G3 hepatitis was reported.

The analysis of the subprotocol National Cancer Institute Molecular Analysis for Therapy Choice (NCI-MATCH) trial showed that the anti PD-1 nivolumab was associated 
with a $12-$ month PFS of $46 \%$ and a median OS of 17.3 months in 42 highly pretreated patients with MMR-d non-colorectal cancer of different types [98]. Nivolumab produced an objective response in $46 \%$ of 13 EC patients. The most common G1 AEs were fatigue, anemia, rash and hypoalbuminemia.

The addition of cabozantinib to nivolumab improved ORR (25\% versus $17 \%)$ and median PFS (5.3 versus 1.9 months) compared with single-agent nivolumab, with an increased toxicity mainly represented by G1-2 diarrhea, liver enzymes elevation, fatigue and hypertension [99].

In the open-label single-arm phase Ib/II study 111/KEYNOTE-146, the combination of lenvatinib (20 mg daily) + pembrolizumab (200 mg Q3W) achieved a 24-week response rate of $38 \%$ in 108 patients with highly pretreated EC, ranging from $64 \%$ in patients with MSI-H/MMR-d to 36\% in those with microsatellite stable (MSS)/MMR-p tumors [100]. There was a robust depth of response, with $84 \%$ of patients having decreased tumor lesions from baseline and $30 \%$ having a maximum decrease of $\geq 50 \%$. A response was detected in $36 \%$ and $40 \%$ of patients with PD-L1-positive and PD-L1-negative tumors, respectively, but these data must be considered with caution because of the uncertainty of the cutoff for PD-L1 positivity. With the exception of hypothyroidism, which occurred in $44 \%$ of the patients, the safety profile of the combination was comparable to that of each agent. Lenvatinib could modulate tumor immunity by decreasing the suppressive tumorassociated macrophage population [101]. A post hoc analysis found that selected AEs, such hypertension, fatigue, nausea/vomiting, diarrhea, decreased appetite/weight loss, hypothyroidism, palmar-plantar erythrodysesthesia, musculoskeletal pain, stomatitis and proteinuria, developed within the first 10 weeks of treatment. $G \geq 3$ fatigue, hypertension and nausea occurred in $\geq 5 \%$ of patients [102]. AEs may be managed with concomitant supportive medications and lenvatinib dose modifications.

How et al. [103], who assessed pembrolizumab + lenvatinib in 70 patients with recurrent EC in a "real-world" clinical setting, found that a reduced starting dose of lenvatinib of $14 \mathrm{mg}$ was associated with a better toxicity profile and similar ORR, PFS and OS compared to the standard $20 \mathrm{mg}$ dose.

\section{Conclusions}

The clinical outcome of patients with metastatic or recurrent EC not suitable for surgery and/or radiotherapy is very poor, and the pharmacologic treatment options have a mainly palliative intent. The combination of PTX + CBDCA is the standard chemotherapy, able to achieve ORRs of 43-62\%, a median PFS of 5.3-15 months, and a median OS of 13.2-37.0 months respectively, whereas hormonal therapy is sometimes used in selected patients with slow growing, ER- and/or PR- positive EC.

Whereas single-agent aromatase inhibitors or m-TOR inhibitors have limited activity, the combination of these agents has resulted in an objective response in approximately $30 \%$ of patients who failed after prior chemotherapy regimens. The association of cyclindependent kinase 4/6 inhibitors and hormonal agents is currently under evaluation.

Clinical trials of EGFR inhibitors, multi-tyrosine kinase inhibitors, and HER2 inhibitors have usually resulted in very disappointing results. However, a phase II trial of patients with advanced or recurrent HER2 positive serous carcinomas showed that the combination of trastuzumab + CBDCA + PTX significantly improved PFS compared with chemotherapy alone. The addition of BEV to CBDCA + PTX improved OS in the NRG Oncology/GOG$86 \mathrm{P}$ trial, but not in the MITO END-2 trial. These conflicting results might be due to both the different chemotherapy settings (first-line versus second-line chemotherapy) and the heterogeneous baseline patient characteristics

We must take into consideration that the low number of patients included in many of the clinical trials might have impacted either or both the outcome of the trials or the potential reproducibility of trial results.

In recent years the implementation of biological knowledge of $\mathrm{EC}$, which has led to a molecular-based classification system, and the positive results obtained with immune 
checkpoint inhibitors have offered novel and promising tools for the treatment of patients with metastatic or recurrent disease. Anti- PD-1 and anti-PD-L1 antibodies have achieved ORRs ranging from $27 \%$ to $47 \%$ in highly pretreated patients with MMR-d EC.

Pembrolizumab received accelerated US Food and Drug Administration (FDA) approval for patients with unresectable or metastatic MSI-H/MMR-d solid tumors regardless of tissue of origin, that have progressed after prior treatment and who have no alternative treatment options.

In the KEYNOTE-146 study the combination of lenvatinib + pembrolizumab has produced an objective response in 36\% of patients with MSS/MMR-p EC. Based on this study, this combination was granted accelerated approval for the patients with advanced, not MSI-H or MMR-d EC who have progressed after systemic therapy and who are not candidates for curative surgery or radiotherapy.

Several randomized phase III trials with immune check point inhibitors are currently ongoing in EC (Table 7).

Table 7. Ongoing clinical trials with immune checkpoint inhibitors in metastatic, advanced or recurrent endometrial cancer.

\begin{tabular}{c} 
Trial \\
\hline NCT03603184 AtTEnd (Atezolizumab \\
Trial in Endometrial Cancer)
\end{tabular}

Trial in Endometrial Cancer)

NCT03914612 NRG-GY018)

NCT04269200

DUO-E/GOG-3041/ENGOT-EN10

NCT03884101

(ENGOT-en9/MK-7902-001, LEAP-001)

NCT03517449 (KEYNOTE-775)

Phase III double-blind randomized placebo-controlled trial of atezolizumab in combination with PTX and CBDCA in patients with newly diagnosed EC with residual disease after surgery either measurable or evaluable, with inoperable stage III-IV EC naïve to first-line systemic treatment and with recurrent EC not yet treated for relapsed disease (estimated study completion: December 2023)

Phase III randomized placebo-controlled study of pembrolizumab in addition to PTX and CBDCA for measurable stage III or IVA, stage IVB or recurrent EC (estimated study completion: June 2023)

Randomized multicenter double-blind placebo-controlled phase III study of first-line CBDCA + PTX in combination with durvalumab followed by maintenance durvalumab with or without olaparib in patients with newly diagnosed advanced or recurrent EC (estimated study completion: March 2025)

Phase III randomized open-label study of pembrolizumab plus lenvatinib versus chemotherapy (CBDCA + PTX) for first-line treatment of advanced or recurrent EOC (estimated study completion: April 2023)

Phase III randomized open-label phase III study comparing the efficacy and safety of pembrolizumab plus lenvatinib versus treatment of physician's choice (weekly PTX or PLD) in patients with advanced, recurrent or metastatic EC (estimated study completion: November 2023)

\begin{tabular}{cc}
\hline NCT04262089 (PAM) & Neo-adjuvant Pembrolizumab in dMMR/ POLE-EDM Uterine Cancer Patients: a Feasibility \\
Study
\end{tabular}

For instance, four trials are investigating the addition of immune checkpoint inhibitors to PTX + CBDCA in primary advanced or recurrent EC (NCT03603184, NCT03914612, NCT04269200, NCT03981796A), one trial (NCT03884101) is comparing pembrolizumab + lenvatinib versus CBDCA + PTX as first-line treatment of advanced or recurrent EC, and another trial (NCT03517449) is comparing pembrolizumab + lenvatinib versus singleagent chemotherapy in patients with advanced, recurrent or metastatic EC after one prior platinum-based chemotherapy. 
Author Contributions: Conceptualization, A.G.; data curation, A.G.; writing-original draft preparation A.G.; writing-review and editing: A.G. and S.C. All authors have read and agreed to the published version of the manuscript.

Funding: This research received no external funding.

Conflicts of Interest: The authors declare no conflict of interest.

\section{References}

1. Bray, F.; Ferlay, J.; Soerjomataram, I.; Siegel, R.L.; Torre, L.A.; Jemal, A. Global cancer statistics 2018: GLOBOCAN estimates of incidence and mortality worldwide for 36 cancers in 185 countries. CA Cancer J. Clin. 2018, 68, 394-424. [CrossRef]

2. Bokhman, J.V. Two pathogenetic types of endometrial carcinoma. Gynecol. Oncol. 1983, 15, 10-17. [CrossRef]

3. Prat, J.; Gallardo, A.; Cuatrecasas, M.; Catasús, L. Endometrial carcinoma: Pathology and genetics. Pathology 2007, 39, 72-87. [CrossRef] [PubMed]

4. Cancer Genome Atlas Research Network; Kandoth, C.; Schultz, N.; Cherniack, A.D.; Akbani, R.; Liu, Y.; Shen, H.; Robertson, A.G.; Pashtan, I.; Shen, R.; et al. Integrated genomic characterization of endometrial carcinoma. Nature 2013, 497, 67-73.

5. Murali, R.; Soslow, R.; Weigelt, B. Classification of endometrial carcinoma: More than two types. Lancet Oncol. 2014, 15, e268-e278. [CrossRef]

6. Talhouk, A.; McConechy, M.K.; Leung, S.; Li-Chang, H.H.; Kwon, J.S.; Melnyk, N.; Yang, W.; Senz, J.; Boyd, N.F.; Karnezis, A.N.; et al. A clinically applicable molecular-based classification for endometrial cancers. Br. J. Cancer 2015, 113, 299-310. [CrossRef]

7. Kommoss, S.; McConechy, M.K.; Kommoss, F.; Leung, S.; Bunz, A.; Magrill, J.; Britton, H.; Grevenkamp, F.; Karnezis, A.; Yang, W.; et al. Final validation of the ProMisE molecular classifier for endometrial carcinoma in a large population-based case series. Ann. Oncol. 2018, 29, 1180-1188. [CrossRef] [PubMed]

8. Stelloo, E.; Bosse, T.; Nout, R.A.; Mackay, H.J.; Church, D.N.; Nijman, H.W.; Leary, A.; Edmondson, R.J.; Powell, M.E.; Crosbie, E.J.; et al. Refining prognosis and identifying targetable pathways for high-risk endometrial cancer; a TransPORTEC initiative. Mod. Pathol. 2015, 28, 836-844. [CrossRef]

9. Stelloo, E.; Nout, R.A.; Osse, E.M.; Jürgenliemk-Schulz, I.J.; Jobsen, J.J.; Lutgens, L.C.; van der Steen-Banasik, E.M.; Nijman, H.W.; Putter, H.; Bosse, T.; et al. Improved risk assessment by integrating molecular and clinicopathological factors in early-stage endometrial cancer-Combined analysis of the PORTEC cohorts. Clin. Cancer Res. 2016, 22, 4215-4224. [CrossRef] [PubMed]

10. León-Castillo, A.; de Boer, S.M.; Powell, M.E.; Mileshkin, L.R.; Mackay, H.J.; Leary, A.; Nijman, H.W.; Singh, N.; Pollock, P.M.; Bessette, P.; et al. Molecular Classification of the PORTEC-3 Trial for High-Risk Endometrial Cancer: Impact on Prognosis and Benefit From Adjuvant Therapy. J. Clin. Oncol. 2020, 38, 3388-3397. [CrossRef] [PubMed]

11. Concin, N.; Matias-Guiu, X.; Vergote, I.; Cibula, D.; Mirza, M.R.; Marnitz, S.; Ledermann, J.; Bosse, T.; Chargari, C.; Fagotti, A.; et al. ESGO/ESTRO/ESP guidelines for the management of patients with endometrial carcinoma. Int. J. Gynecol. Cancer 2021, 31, 12-39. [CrossRef] [PubMed]

12. Berchuck, A.; Anspach, C.; Evans, A.C.; Soper, J.T.; Rodriguez, G.C.; Dodge, R.; Robboy, S.; Clarke-Pearson, D.L. Postsurgical Surveillance of Patients with FIGO Stage I/II Endometrial Adenocarcinoma. Gynecol. Oncol. 1995, 59, 20-24. [CrossRef] [PubMed]

13. Reddoch, J.M.; Burke, T.W.; Morris, M.; Tornos, C.; Levenback, C.; Gershenson, D.M. Surveillance for Recurrent Endometrial Carcinoma: Development of a Follow-up Scheme. Gynecol. Oncol. 1995, 59, 221-225. [CrossRef]

14. Salvesen, H.B.; Akslen, L.A.; Iversen, T.; Iversen, O.E. Recurrence of endometrial carcinoma and the value of routine follow up. Br. J. Obstet. Gynaecol. 1997, 104, 1302-1307. [CrossRef]

15. Sartori, E.; Laface, B.; Gadducci, A.; Maggino, T.; Zola, P.; Landoni, F.; Zanagnolo, V. Factors influencing survival in endometrial cancer relapsing patients: A Cooperation Task Force (CTF) study. Int. J. Gynecol. Cancer 2003, 13, 458-465. [CrossRef]

16. Fung-Kee-Fung, M.; Dodge, J.; Elit, L.; Lukka, H.; Chambers, A.; Oliver, T. Cancer Care Ontario Program in Evidence-based Care Gynecology Cancer Disease Site Group Follow-up after primary therapy for endometrial cancer: A systematic review. Gynecol. Oncol. 2006, 101, 520-529. [CrossRef]

17. Sartori, E.; Pasinetti, B.; Chiudinelli, F.; Gadducci, A.; Landoni, F.; Maggino, T.; Piovano, E.; Zola, P. Surveillance Procedures for Patients Treated for Endometrial Cancer: A Review of the Literature. Int. J. Gynecol. Cancer 2010, 20, 985-992. [CrossRef] [PubMed]

18. de Lange, N.M.; Ezendam, N.P.; Kwon, J.S.; Vandenput, I.; Mirchandani, D.; Amant, F.; van der Putten, L.J.; Pijnenborg, J.M. Neoadjuvant Chemotherapy Followed by Surgery for Advanced-Stage Endometrial Cancer. Curr. Oncol. 2019, $26,226-232$. [CrossRef] [PubMed]

19. Tropé, C.; Johnsson, J.E.; Simonsen, E.; Christiansen, H.; Cavallin-Ståhl, E.; Horváth, G. Treatment of recurrent endometrial adeno-carcinoma with a combination of doxorubicin and cisplatin. Am. J. Obstet. Gynecol. 1984, 149, 379-381. [CrossRef]

20. van Wijk, F.H.; Aapro, M.S.; Bolis, G.; Chevallier, B.; van der Burg, M.E.; Poveda, A.; de Oliveira, C.F.; Tumolo, S.; Scotto di Palumbo, V.; Piccart, M.; et al. Doxorubicin versus doxorubicin and cisplatin in endometrial carcinoma: Definitive results of a randomised study (55872) by the EORTC Gynaecological Cancer Group. Ann. Oncol. 2003, 14, 441-448.

21. Thigpen, J.T.; Brady, M.F.; Homesley, H.D.; Malfetano, J.; DuBeshter, B.; Burger, R.A.; Liao, S. Phase III Trial of Doxorubicin With or Without Cisplatin in Advanced Endometrial Carcinoma: A Gynecologic Oncology Group Study. J. Clin. Oncol. 2004, 22, 3902-3908. [CrossRef] [PubMed] 
22. Fleming, G.F.; Brunetto, V.L.; Cella, D.; Look, K.Y.; Reid, G.C.; Munkarah, A.R.; Kline, R.; Burger, R.A.; Goodman, A.; Burks, R.T. Phase III trial of doxorubicin plus cisplatin with or without paclitaxel plus filgrastim in advanced endometrial carcinoma: A Gynecologic Oncology Group Study. J. Clin. Oncol. 2004, 22, 2159-2166. [CrossRef] [PubMed]

23. Miller, D.S.; Filiaci, V.L.; Mannel, R.S.; Cohn, D.E.; Matsumoto, T.; Tewari, K.S.; DiSilvestro, P.; Pearl, M.L.; Argenta, P.A.; Powell, M.A.; et al. Carboplatin and Paclitaxel for Advanced Endometrial Cancer: Final Overall Survival and Adverse Event Analysis of a Phase III Trial (NRG Oncology/GOG0209). J. Clin. Oncol. 2020, 38, 3841-3850. [CrossRef] [PubMed]

24. Sovak, M.A.; Dupont, J.; Hensley, M.L.; Ishill, N.; Gerst, S.; Abu-Rustum, N.; Anderson, S.; Barakat, R.; Konner, J.; Poyner, E.; et al. Paclitaxel and carboplatin in the treatment of advanced or recurrent endometrial cancer: A large retrospective study. Int. J. Gynecol. Cancer 2007, 17, 197-203. [CrossRef]

25. Pectasides, D.; Xiros, N.; Papaxoinis, G.; Sykiotis, C.; Koumarianou, A.; Psyrri, A.; Gaglia, A.; Kassanos, D.; Gouveris, P.; Panayiotidis, J.; et al. Carboplatin and paclitaxel in advanced or metastatic endometrial cancer. Gynecol. Oncol. 2008, 109, 250-254. [CrossRef] [PubMed]

26. Lorusso, D.; Ferrandina, G.; Colombo, N.; Pignata, S.; Pietragalla, A.; Sonetto, C.; Pisano, C.; Lapresa, M.T.; Savarese, A.; Tagliaferri, P.; et al. Carboplatin-paclitaxel compared to Carboplatin-Paclitaxel-Bevacizumab in advanced or recurrent endometrial cancer: MITO END-2-A randomized phase II trial. Gynecol. Oncol. 2019, 155, 406-412.

27. McMeekin, D.S.; Filiaci, V.L.; Thigpen, J.T.; Gallion, H.H.; Fleming, G.F.; Rodgers, W.H. Gynecologic Oncology Group study. The relationship between histology and outcome in advanced and recurrent endometrial cancer patients participating in first-line chemotherapy trials: A Gynecologic Oncology Group study. Gynecol. Oncol. 2007, 106, 16-22. [CrossRef]

28. Nagao, S.; Nishio, S.; Michimae, H.; Tanabe, H.; Okada, S.; Otsuki, T.; Tanioka, M.; Fujiwara, K.; Suzuki, M.; Kigawa, J. Applicability of the concept of "platinum sensitivity" to recurrent endometrial cancer: The SGSG-012/GOTIC-004/Intergroup study. Gynecol. Oncol. 2013, 131, 567-573. [CrossRef]

29. Lissoni, A.; Zanetta, G.; Losa, G.; Gabriele, A.; Parma, G.; Mangioni, C. Phase II study of paclitaxel as salvage treatment in advanced endometrial cancer. Ann. Oncol. 1996, 7, 861-863. [CrossRef]

30. Lincoln, S.; Blessing, J.A.; Lee, R.B.; Rocereto, T.F. Activity of paclitaxel as second-line chemotherapy in endometrial carcinoma: A Gynecologic Oncology Group study. Gynecol. Oncol. 2003, 88, 277-281. [CrossRef]

31. Homesley, H.D.; Meltzer, N.P.; Nieves, L.; Vaccarello, L.; Lowendowski, G.S.; Elbendary, A.A. A phase II trial of weekly 1-hour paclitaxel as second-line therapy for endometrial and cervical cancer. Int. J. Clin. Oncol. 2008, 13, 62-65. [CrossRef] [PubMed]

32. Markman, M.; Fowler, J. Activity of weekly paclitaxel in patients with advanced endometrial cancer previously treated with both a platinum agent and paclitaxel. Gynecol. Oncol. 2004, 92, 180-182. [CrossRef]

33. Sutton, G.P.; Blessing, J.A.; Homesley, H.D.; McGuire, W.P.; Adcock, L. A Gynecologic Oncology Group Study Phase II study of Ifosfamide and Mesna in refractory adenocarcinoma of the endometrium. Cancer 1994, 73, 1453-1455. [CrossRef]

34. Rose, P.G.; Blessing, J.A.; Lewandowski, G.S.; Creasman, W.T.; Webster, K.D. A Phase II Trial of Prolonged Oral Etoposide (VP-16) as Second-Line Therapy for Advanced and Recurrent Endometrial Carcinoma: A Gynecologic Oncology Group Study. Gynecol. Oncol. 1996, 63, 101-104. [CrossRef] [PubMed]

35. Miller, D.S.; Blessing, J.A.; Lentz, S.S.; Waggoner, S.E. A Phase II Trial of Topotecan in Patients with Advanced, Persistent, or Recurrent Endometrial Carcinoma: A Gynecologic Oncology Group Study. Gynecol. Oncol. 2002, 87, 247-251. [CrossRef] [PubMed]

36. Fracasso, P.M.; Blessing, J.A.; Molpus, K.L.; Adler, L.M.; Sorosky, J.I.; Rose, P.G. Phase II study of oxaliplatin as second-line chemotherapy in endometrial carcinoma: A Gynecologic Oncology Group study. Gynecol. Oncol. 2006, 103, 523-526. [CrossRef]

37. Dizon, D.S.; Blessing, J.A.; McMeekin, D.S.; Sharma, S.K.; Disilvestro, P.; Alvarez, R.D. Phase II trial of ixabepilone as second-line treatment in advanced endometrial cancer: Gynecologic oncology group trial 129-P. J. Clin. Oncol. 2009, 27, 3104-3108. [CrossRef]

38. McMeekin, S.; Dizon, D.; Barter, J.; Scambia, G.; Manzyuk, L.; Lisyanskaya, A.; Oaknin, A.; Ringuette, S.; Mukhopadhyay, P.; Rosenberg, J.; et al. Phase III randomized trial of second-line ixabepilone versus paclitaxel or doxorubicin in women with advanced endometrial cancer. Gynecol. Oncol. 2015, 138, 18-23. [CrossRef]

39. Miller, D.S.; Blessing, J.A.; Drake, R.D.; Higgins, R.; McMeekin, D.S.; Puneky, L.V.; Krasner, C.N. A phase II evaluation of pemetrexed (Alimta, LY231514, IND \#40061) in the treatment of recurrent or persistent endometrial carcinoma: A phase II study of the Gynecologic Oncology. Gynecol. Oncol. 2009, 115, 443-446. [CrossRef]

40. Tait, D.L.; Blessing, J.A.; Hoffman, J.S.; Moore, K.N.; Spirtos, N.M.; Lachance, J.A.; Rotmensch, J.; Miller, D.S. A phase II study of gemcitabine (gemzar, LY188011) in the treatment of recurrent or persistent endometrial carcinoma: A gynecologic oncology group study. Gynecol. Oncol. 2011, 121, 118-121. [CrossRef]

41. Makker, V.; Hensley, M.L.; Zhou, Q.; Iasonos, A.; Aghajanian, C.A. Treatment of advanced or recurrent endometrial carcinoma with doxorubicin in patients progressing after paclitaxel/carboplatin: Memorial Sloan-Kettering Cancer Center experience from 1995 to. Int. J. Gynecol. Cancer 2013, 23, 929-934. [CrossRef] [PubMed]

42. Moreira, E.; Paulino, E.; Garces, A.I.R.; Dias, M.S.F.; Saramago, M.; Silva, F.D.M.L.D.; Thuler, L.C.S.; De Melo, A.C. Efficacy of doxorubicin after progression on carboplatin and paclitaxel in advanced or recurrent endometrial cancer: A retrospective analysis of patients treated at the Brazilian National Cancer Institute (INCA). Med. Oncol. 2018, 35, 20. [CrossRef]

43. Muggia, F.; Blessing, J.A.; Sorosky, J.; Reid, G.C. Phase II Trial of the Pegylated Liposomal Doxorubicin in Previously Treated Metastatic Endometrial Cancer: A Gynecologic Oncology Group Study. J. Clin. Oncol. 2002, 20, 2360-2364. [CrossRef]

44. Piver, M.S.; Barlow, J.J.; Lurain, J.R.; Blumenson, L.E. Medroxyprogesterone acetate (Depo-Provera) vs. hydroxyprogester-one caproate (Delalutin) in women with metastatic endometrial adenocarcinoma. Cancer 1980, 45, 268-272. [CrossRef] 
45. Podratz, K.C.; O’Brien, P.C.; Malkasian, G.D.; Decker, D.G.; Jefferies, J.; Edmonson, J.H. Effects of progestational agents in treatment of endometrial carcinoma. Obstet. Gynecol. 1985, 66, 106-110.

46. Thigpen, J.T.; Brady, M.F.; Alvarez, R.D.; Adelson, M.D.; Homesley, H.D.; Manetta, A.; Soper, J.T.; Given, F.T. Oral medroxyprogesterone acetate in the treatment of advanced or recurrent endometrial carcinoma: A dose-response study by the Gynecologic Oncology Group. J. Clin. Oncol. 1999, 17, 1736-1744. [CrossRef]

47. Pandya, K.J.; Yeap, B.Y.; Weiner, L.M.; Krook, J.E.; Erban, J.K.; Schinella, R.A.; Davis, T.E. Megestrol and tamoxifen in patients with advanced endometrial cancer: An Eastern Cooperative Oncology Group Study (E4882). Am. J. Clin. Oncol. 2001, 24, 43-46. [CrossRef]

48. Thigpen, T.; Brady, M.F.; Homesley, H.D.; Soper, J.T.; Bell, J.J. Tamoxifen in the treatment of advanced or recurrent endometrial carcinoma: A Gynecologic Oncology Group study. J. Clin. Oncol. 2001, 19, 364-367. [CrossRef] [PubMed]

49. Carlson, J.A.; Allegra, J.C.; Day, T.G.; Wittliff, J.L. Tamoxifen and endometrial carcinoma: Alterations in estrogen and progesterone receptors in untreated patients and combination hormonal therapy in advanced neoplasia. Am. J. Obstet. Gynecol. 1984, 149, 149-153. [CrossRef]

50. Whitney, C.W.; Brunetto, V.L.; Zaino, R.J.; Lentz, S.S.; Sorosky, J.; Armstrong, D.K.; Lee, R.B. Phase II study of medroxyprogesterone acetate plus tamoxifen in advanced endometrial carcinoma: A Gynecologic Oncology Group study. Gynecol. Oncol. 2004, 92, 4-9. [CrossRef]

51. Fiorica, J.V.; Brunetto, V.L.; Hanjani, P.; Lentz, S.S.; Mannel, R.; Andersen, W. Phase II trial of alternating courses of megestrol acetate and tamoxifen in advanced endometrial carcinoma: A Gynecologic Oncology Group study. Gynecol. Oncol. 2004, 92, 10-11. [CrossRef] [PubMed]

52. Rose, P.G.; Brunetto, V.L.; VanLe, L.; Bell, J.; Walker, J.L.; Lee, R.B. A Phase II Trial of Anastrozole in Advanced Recurrent or Persistent Endometrial Carcinoma: A Gynecologic Oncology Group Study. Gynecol. Oncol. 2000, 78, 212-216. [CrossRef] [PubMed]

53. Ma, B.B.; Oza, A.; Eisenhauer, E.; Stanimir, G.; Carey, M.; Chapman, W.; Latta, E.; Sidhu, K.; Powers, J.; Walsh, W.; et al. The activity of letrozole in patients with advanced or recurrent endometrial cancer and correlation with biological markers-A study of the National Cancer Institute of Canada Clinical Trials Group. Int. J. Gynecol. Cancer 2004, 14, 650-658.

54. Covens, A.L.; Filiaci, V.; Gersell, D.; Lutman, C.V.; Bonebrake, A.; Lee, Y.C. Phase II study of fulvestrant in recurrent/metastatic endometrial carcinoma: A Gynecologic Oncology Group study. Gynecol. Oncol. 2011, 120, 185-188. [CrossRef] [PubMed]

55. Emons, G.; Günthert, A.; Thiel, F.C.; Camara, O.; Strauss, H.-G.; Breitbach, G.-P.; Kölbl, H.; Reimer, T.; Finas, D.; Rensing, K. Phase II study of fulvestrant $250 \mathrm{mg} /$ month in patients with recurrent or metastatic endometrial cancer: A study of the Arbeitsgemeinschaft Gynäkologische Onkologie. Gynecol. Oncol. 2013, 129, 495-499. [CrossRef] [PubMed]

56. Tanaka, T.; Terai, Y.; Ashihara, K.; Fujiwara, S.; Tanaka, Y.; Sasaki, H.; Tsunetoh, S.; Ohmichi, M. The efficacy of the cyclindependent kinase 4/6 inhibitor in endometrial cancer. PLoS ONE 2017, 12, e0177019. [CrossRef]

57. Lin, C.-Y.; Lee, L.-Y.; Wang, T.-H.; Hsu, C.-L.; Tsai, C.-L.; Chao, A.; Lai, C.-H. Palbociclib Promotes Dephosphorylation of NPM/B23 at Threonine 199 and Inhibits Endometrial Cancer Cell Growth. Cancers 2019, 11, 1025. [CrossRef]

58. Colon-Otero, G.; Zanfagnin, V.; Hou, X.; Foster, N.R.; Asmus, E.J.; Hendrickson, A.W.; Jatoi, A.; Block, M.S.; Langstraat, C.L.; Glaser, G.E.; et al. Phase II trial of ribociclib and letrozole in patients with relapsed oestrogen receptor-positive ovarian or endometrial cancers. ESMO Open. 2020, 5, e000926. [CrossRef]

59. Mirza, M.R.; Bjorgen, L.; Marmè, F.; DePont Christensen, R.; Gil-Martin, M.; Auranen, A.; Ataseven, B.; Rubio, M.J.; Salutari, V.; Lund, B.; et al. BA28 A randomised double-blind placebo-controlled phase II trial of palbociclib combined with letrozole (L) in patients (pts) with oestrogen receptor-positive (ER+) advanced/recurrent endometrial cancer (EC): NSGO-PALEO/ENGOT-EN3 trial. Annals. Oncol. 2020, 31, S1160. [CrossRef]

60. Raycoquard, I.; Favier, L.; Weber, B.L.; Roemer-Becuwe, C.; Bougnoux, P.; Fabbro, M.; Floquet, A.; Joly, F.; Plantade, A.; Paraiso, D.; et al. Everolimus as second- or third-line treatment of advanced endometrial cancer: ENDORAD, a phase II trial of GINECO. Br. J. Cancer 2013, 108, 1771-1777. [CrossRef]

61. Colombo, N.; McMeekin, D.S.; Schwartz, P.; Sessa, C.; Gehrig, P.; Holloway, R.; Braly, P.; Matei, D.; Morosky, A.; Dodion, P.F.; et al. Ridaforolimus as a single agent in advanced endometrial cancer: Results of a singlearm, phase 2 trial. Br. J. Cancer 2013, 108, 1021-1026. [CrossRef]

62. Tsoref, D.; Welch, S.; Lau, S.; Biagi, J.; Tonkin, K.; Martin, L.A.; Ellard, S.; Ghatage, P.; Elit, L.; Mackay, H.J.; et al. Phase II study of oral ridaforolimus in women with recurrent or metastatic endometrial cancer. Gynecol. Oncol. 2014, 135, 184-189. [CrossRef] [PubMed]

63. Oza, A.M.; Pignata, S.; Poveda, A.; McCormack, M.; Clamp, A.; Schwartz, B.; Cheng, J.; Li, X.; Campbell, K.; Dodion, P.; et al. Random-ized Phase II Trial of Ridaforolimus in Advanced Endometrial Carcinoma. J. Clin. Oncol. 2015, 33, 3576-3582. [CrossRef] [PubMed]

64. Oza, A.M.; Elit, L.; Tsao, M.; Kamel-Reid, S.; Biagi, J.; Provencher, D.M.; Gotlieb, W.H.; Hoskins, P.J.; Ghatage, P.; Tonkin, K.S.; et al. Phase II Study of Temsirolimus in Women with Recurrent or Metastatic Endometrial Cancer: A Trial of the NCIC Clinical Trials Group. J. Clin. Oncol. 2011, 29, 3278-3285. [CrossRef] [PubMed]

65. Fleming, G.F.; Filiaci, V.L.; Marzullo, B.; Zaino, R.J.; Davidson, S.A.; Pearl, M.; Makker, V.; Burke, J.J., 2nd; Zweizig, S.L.; Van Le, L.; et al. Temsirolimus with or without megestrol acetate and tamoxifen for endometrial cancer: A gynecologic oncology group study. Gynecol. Oncol. 2014, 132, 585-592. [CrossRef] [PubMed] 
66. Slomovitz, B.M.; Jiang, Y.; Yates, M.S.; Soliman, P.T.; Johnston, T.; Nowakowski, M.; Levenback, C.; Zhang, Q.; Ring, K.; Munsell, M.F.; et al. Phase II Study of Everolimus and Letrozole in Patients With Recurrent Endometrial Carcinoma. J. Clin. Oncol. 2015, 33, 930-936. [CrossRef]

67. Soliman, P.T.; Westin, S.N.; Iglesias, D.A.; Fellman, B.M.; Yuan, Y.; Zhang, Q.; Yates, M.S.; Broaddus, R.R.; Slomovitz, B.M.; Lu, K.H.; et al. Everolimus, letrozole, and metformin in women with advanced or recurrent endometrioid endometrial cancer: A multicenter, single arm, phase II study. Clin. Cancer Res. 2020, 26, 581-587. [CrossRef]

68. Heudel, P.; Frenel, J.S.; Dalban, C.; Bazan, F.; Joly, F.; Arnaud, A.; Abdeddaim, C.; Chevalier, A.; Augereau, P.; Pautier, C.; et al. Victoria: A multicentric, randomized, open-label, phase I/II of mTOR inhibitor (VISTUSERTIB) combined with anastrozole in patients with hormone receptor-positive advanced/metastatic endometrial cancer-A CLIPP program INCA in collaboration with GINECO group. J. Clin. Oncol. 2021, 39 (Suppl. S15), Abstr 5507. [CrossRef]

69. Oza, A.M.; Eisenhauer, E.A.; Elit, L.; Cutz, J.-C.; Sakurada, A.; Tsao, M.S.; Hoskins, P.J.; Biagi, J.; Ghatage, P.; Mazurka, J.; et al. Phase II Study of Erlotinib in Recurrent or Metastatic Endometrial Cancer: NCIC IND. J. Clin. Oncol. 2008, 26, 4319-4325. [CrossRef]

70. $\quad$ Leslie, K.K.; Sill, M.W.; Fischer, E.; Darcy, K.M.; Mannel, R.S.; Tewari, K.S.; Hanjani, P.; Wilken, J.A.; Baron, A.T.; Godwin, A.K.; et al. A phase II evaluation of gefitinib in the treatment of persistent or recurrent endometrial cancer: A Gynecologic Oncology Group study. Gynecol. Oncol. 2013, 129, 486-494. [CrossRef]

71. Fleming, G.F.; Sill, M.W.; Darcy, K.M.; McMeekin, D.S.; Thigpen, J.T.; Adler, L.M.; Berek, J.S.; Chapman, J.A.; DiSilvestro, P.A.; Horowitz, I.R.; et al. Phase II trial of trastuzumab in women with advanced or recurrent, HER2-positive endometrial carcinoma: A Gynecologic Oncology Group study. Gynecol. Oncol. 2010, 116, 15-20. [CrossRef]

72. Leslie, K.K.; Sill, M.W.; Lankes, H.A.; Fischer, E.G.; Godwin, A.K.; Gray, H.; Schilder, R.J.; Walker, J.L.; Tewari, K.; Hanjani, P.; et al. Lapatinib and potential prognostic value of EGFR mutations in a Gynecologic Oncology Group phase II trial of persistent or recurrent endometrial cancer. Gynecol. Oncol. 2012, 127, 345-350. [CrossRef] [PubMed]

73. Fader, A.N.; Roque, D.M.; Siegel, E.; Buza, N.; Hui, P.; Abdelghany, O.; Chambers, S.K.; Secord, A.A.; Havrilesky, L.; O’Malley, D.M.; et al. Randomized phase II trial of carboplatin-paclitaxel versus carboplatin-paclitaxel-trastuzumab in uterine serous carcinomas that overexpress human Epidermal Growth Factor Receptor 2/neu. J. Clin. Oncol. 2018, 36, 2044-2051. [CrossRef] [PubMed]

74. Ali-Ahmad, H.M.; Rothe, M.; Mangat, P.K.; Garrett-Mayer, L.; Ahn, E.; Chan, J.; Maitland, M.L.; Ani, S.; Balmanoukian, A.S.; Patel, S.R.; et al. Pertuzumab plus trastuzumab (P+T) in patients (Pts) with uterine cancer (UC) with ERBB2 or ERBB3 amplification, overexpression or mutation: Results from the Targeted Agent and Profiling Utilization Registry (TAPUR) study. J. Clin. Oncol. 2021, 39, Abstr 5508. [CrossRef]

75. Coleman, R.L.; Sill, M.W.; Thaker, P.H.; Bender, D.P.; Street, D.; McGuire, W.P.; Johnston, C.M.; Rotmensch, J. A phase II evaluation of selumetinib (AZD6244, ARRY-142886), a selective in the treatment of recurrent or persistent endometrial cancer: An NRG Oncology/Gynecologic Oncology Group study. Gynecol. Oncol. 2015, 138, 30-35. [CrossRef]

76. Dhani, N.C.; Hirte, H.W.; Wang, L.; Burnier, J.V.; Jain, A.; Butler, M.O.; Welch, S.; Fleming, G.F.; Hurteau, J.; Matsuo, K.; et al. Phase II Trial of Cabozantinib in Recurrent/Metastatic Endometrial Cancer: A Study of the Princess Margaret, Chicago, and California Consortia (NCI9322/PHL86). Clin. Cancer Res. 2020, 26, 2477-2486. [CrossRef]

77. Nimeiri, H.S.; Oza, A.M.; Morgan, R.J.; Huo, D.; Elit, L.; Knost, J.A.; Wade, J.L., 3rd; Agamah, E.; Vokes, E.E.; Fleming, G.F. A phase II study of sorafenib in advanced uterine carcinoma/carcinosarcoma: A trial of the Chicago, PMH, and California Phase II Consortia. Gynecol. Oncol. 2010, 117, 37-40. [CrossRef] [PubMed]

78. Castonguay, V.; Lheureux, S.; Welch, S.; Mackay, H.J.; Hirte, H.; Fleming, G.; Morgan, R.; Wang, L.; Blattler, C.; Ivy, P.S.; et al. A phase II trial of sunitinib in women with metastatic or recurrent endometrial carcinoma: A study of the Princess Margaret, Chicago and California Consortia. Gynecol. Oncol. 2014, 134, 274-280. [CrossRef] [PubMed]

79. Dizon, D.S.; Sill, M.W.; Schilder, J.M.; McGonigle, K.F.; Rahman, Z.; Miller, D.S.; Mutch, D.G.; Leslie, K.K. A phase II evaluation of nintedanib (BIBF-1120) in the treatment of recurrent or persistent endometrial cancer: An NRG Oncology/Gynecologic Oncology Group Study. Gynecol. Oncol. 2014, 135, 441-445. [CrossRef] [PubMed]

80. Bender, D.; Sill, M.W.; Lankes, H.A.; Reyes, H.D.; Darus, C.J.; Delmore, J.E.; Rotmensch, J.; Gray, H.J.; Mannel, R.S.; Schilder, J.M.; et al. A phase II evaluation of cediranib in the treatment of recurrent or persistent endometrial cancer: An NRG Oncology/Gynecologic Oncology Group study. Gynecol. Oncol. 2015, 138, 507-512. [CrossRef]

81. Vergote, I.; Powell, M.A.; Teneriello, M.G.; Miller, D.; Garcia, A.A.; Mikheeva, O.N.; Bidzinski, M.; Cebotaru, C.L.; Dutcus, C.E.; Ren, M.; et al. Second-line lenvatinib in patients with recurrent endometrial cancer. Gynecol. Oncol. 2020, 156, 575-582. [CrossRef]

82. Oliner, J.; Min, H.; Leal, J.; Yu, D.; Rao, S.; You, E.; Tang, X.; Kim, H.; Meyer, S.; Han, S.J.; et al. Suppression of angiogenesis and tumor growth by selective inhibition of angiopoietin. Cancer Cell 2004, 6, 507-516. [CrossRef] [PubMed]

83. Coxon, A.; Bready, J.; Min, H.; Kaufman, S.; Leal, J.; Yu, D.; Lee, T.A.; Sun, J.R.; Estrada, J.; Bolon, B.; et al. Context dependent role of angiopoietin 1 inhibition in the suppression of angiogenesis and tumor growth: Implications for AMG 386, an angiopoietin 1-2 neutralizing peptibody. Mol. Cancer Ther. 2010, 9, 2641-2651. [CrossRef] [PubMed]

84. Moore, K.N.; Sill, M.W.; Tenney, M.E.; Darus, C.J.; Griffin, D.; Werner, T.L.; Rose, P.G.; Behrens, R. A phase II trial of trebananib (AMG 386; IND\#111071), a selective angiopoietin 1/2 neutralizing peptibody, in patients with persistent/recurrent carcinoma of the endometrium: An NRG/Gynecologic Oncology Group trial. Gynecol. Oncol. 2015, 138, 513-518. [CrossRef] 
85. Coleman, R.L.; Sill, M.W.; Lankes, H.A.; Fader, A.N.; Finkler, N.J.; Hoffman, J.S.; Rose, P.G.; Sutton, G.P.; Drescher, C.W.; McMeekin, D.S.; et al. A phase II evaluation of aflibercept in the treatment of recurrent or persistent endometrial cancer: A Gynecologic Oncology Group study. Gynecol. Oncol. 2012, 127, 538-543. [CrossRef]

86. Aghajanian, C.; Sill, M.W.; Darcy, K.M.; Greer, B.; McMeekin, D.S.; Rose, P.G.; Rotmensch, J.; Barnes, M.N.; Hanjani, P.; Leslie, K. Phase II Trial of Bevacizumab in Recurrent or Persistent Endometrial Cancer: A Gynecologic Oncology Group Study. J. Clin. Oncol. 2011, 29, 2259-2265. [CrossRef]

87. Aghajanian, C.; Filiaci, V.; Dizon, D.S.; Carlson, J.W.; Powell, M.A.; Secord, A.A.; Tewari, K.S.; Bender, D.P.; O’Malley, D.M.; Stuckey, A.; et al. A phase II study of frontline paclitaxel/ carboplatin / bevacizumab, paclitaxel/ carboplatin/ temsirolimus, or ixabepilone / carboplatin/ bevacizumab in advanced/recurrent endometrial cancer. Gynecol. Oncol. 2018, 150, $274-281$. [CrossRef]

88. Leslie, K.K.; Filiaci, V.L.; Mallen, A.R.; Thiel, K.W.; Devor, E.J.; Moxley, K.; Richardson, D.; Mutch, D.; Secord, A.A.; Tewari, K.S.; et al. Mutated p53 portends improvement in outcomes when bevacizumab is combined with chemotherapy in advanced/recurrent endometrial cancer: An NRG Oncology study. Gynecol. Oncol. 2021, 161, 113-121. [CrossRef]

89. Marabelle, A.; Le, D.T.; Ascierto, P.A.; Di Giacomo, A.M.; De Jesus-Acosta, A.; Delord, J.-P.; Geva, R.; Gottfried, M.; Penel, N.; Hansen, A.R.; et al. Efficacy of Pembrolizumab in Patients with Noncolorectal High Microsatellite Instability/Mismatch Repair-Deficient Cancer: Results from the Phase II KEYNOTE-158 Study. J. Clin. Oncol. 2020, 38, 1-10. [CrossRef] [PubMed]

90. Ott, P.A.; Bang, Y.-J.; Berton-Rigaud, D.; Elez, E.; Pishvaian, M.J.; Rugo, H.S.; Puzanov, I.; Mehnert, J.M.; Aung, K.L.; Lopez, J.; et al. Safety and Antitumor Activity of Pembrolizumab in Advanced Programmed Death Ligand 1-Positive Endometrial Cancer: Results from the KEYNOTE-028 Study. J. Clin. Oncol. 2017, 35, 2535-2541. [CrossRef] [PubMed]

91. Mehnert, J.M.; Panda, A.; Zhong, J.; Hirshfield, K.; Damare, S.; Lane, K.; Sokol, L.; Stein, M.N.; Rodriguez-Rodriquez, L.; Kaufman, H.L.; et al. Immune activation and response to pembrolizumab in POLE-mutant endometrial cancer. J. Clin. Investig. 2016, 126, 2334-2340. [CrossRef]

92. Marcus, L.; Lemery, S.J.; Keegan, P.; Pazdur, R. FDA Approval Summary: Pembrolizumab for the Treatment of Microsatellite Instability-High Solid Tumors. Clin. Cancer Res. 2019, 2, 3753-3758. [CrossRef] [PubMed]

93. Konstantinopoulos, P.A.; Luo, W.; Liu, J.F.; Gulhan, D.C.; Krasner, C.; Ishizuka, J.J.; Gockley, A.A.; Buss, M.; Growdon, W.B.; Crowe, H.; et al. Phase II study of avelumab in patients with mismatch repair deficient and mismatch repair proficient recurrent/persistent endometrial cancer. J. Clin. Oncol. 2019, 37, 2786-2794. [CrossRef]

94. Zaretsky, J.M.; Garcia-Diaz, A.; Shin, D.S.; Escuin-Ordinas, H.; Hugo, W.; Hu-Lieskovan, S.; Torrejon, D.Y.; Abril-Rodriguez, G.; Sandoval, S.; Barthly, L.; et al. Mutations Associated with Acquired Resistance to PD-1 Blockade in Melanoma. N. Engl. J. Med. 2016, 375, 819-829. [CrossRef] [PubMed]

95. Oaknin, A.; Tinker, A.V.; Gilbert, L.; Samouëlian, V.; Mathews, C.; Brown, J.; Barretina-Ginesta, M.P.; Moreno, V.; Gravina, A.; Abdeddaim, C.; et al. Clinical activity and safety of the anti-programmed death 1 monoclonal antibody dostarlimab for patients with recurrent or advanced mismatch repair-deficient endometrial cancer: A nonrandomized phase 1 clinical trial. JAMA Oncol. 2020, 6, 1766-1772. [CrossRef]

96. Liu, J.F.; Gordon, M.; Veneris, J.; Braiteh, F.; Balmanoukian, A.; Eder, J.P.; Oaknin, A.; Hamilton, E.; Wang, Y.; Sarksr, I.; et al. Safety, clinical activity and biomarker assessments of atezolizumab from a Phase I study in advanced/recurrent ovarian and uterine cancers. Gynecol. Oncol. 2019, 154, 314-322. [CrossRef] [PubMed]

97. Antill, Y.; Kok, P.S.; Robledo, K.; Yip, S.; Cummins, M.; Smith, D.; Spurdle, A.; Barnes, E.; Lee, Y.C.; Friedlander, M.; et al. Clinical activity of durvalumab for patients with advanced mismatch repair-deficient and repair-proficient endometrial cancer. A nonrandomized phase 2 clinical trial. J. Immunother. Cancer 2021, 9, e002255. [CrossRef]

98. Azad, N.S.; Gray, R.J.; Overman, M.J.; Schoenfeld, J.D.; Mitchell, E.P.; Zwiebel, J.A.; Sharon, E.; Streicher, H.; Li, S.; McShane, L.M.; et al. Nivolumab Is Effective in Mismatch Repair-Deficient Noncolorectal Cancers: Results from Arm Z1D-A Subprotocol of the NCI-MATCH (EAY131) Study. J. Clin. Oncol. 2020, 38, 214-222. [CrossRef] [PubMed]

99. Lheureux, S.; Matei, D.; Konstantinopoulos, P.A.; Block, M.S.; Jewell, A.; Gaillard, S.; McHale, M.S.; McCourt, C.K.; Temkin, S.; Girda, E.; et al. A randomized phase II study of cabozantinib and nivolumab versus nivolumab in recurrent endometrial cancer. $J$. Clin. Oncol. 2020, 38, 6010. [CrossRef]

100. Makker, V.; Taylor, M.H.; Aghajanian, C.; Oaknin, A.; Mier, J.; Cohn, A.L.; Romeo, M.; Bratos, R.; Brose, M.S.; DiSimone, C.; et al. Lenvatinib plus pembrolizumab in patients with advanced endometrial cancer. J. Clin. Oncol. 2020, 38, 2981-2992. [CrossRef] [PubMed]

101. Kato, Y.; Tabata, K.; Kimura, T.; Yachie-Kinoshita, A.; Ozawa, Y.; Yamada, K.; Ito, J.; Tachino, S.; Hori, Y.; Matsuki, M.; et al. Lenvatinib plus anti-PD-1 antibody combination treatment activates CD8+ T cells through reduction of tumor-associated macrophage and activation of the interferon pathway. PLoS ONE 2019, 14, e0212513. [CrossRef] [PubMed]

102. Makker, V.; Taylor, M.H.; Oaknin, A.; Casado Herraez, A.; Orlowski, R.; Dutta, L.; Ren, M.; Zale, M.; O'Malley, D.M. Characterization and management of adverse reactions in patients with advanced endometrial carcinoma treated with lenvatinib plus pembrolizumab. Oncologist 2021, 26, e1599-e1608. [CrossRef] [PubMed]

103. How, J.A.; Patel, S.; Fellman, B.; Lu, K.H.; Hwu, P.; Ramondetta, L.M.; Westin, S.N.; Fleming, N.D.; Soliman, P.T.; Jazaeri, A.A. Toxicity and efficacy of the combination of pembrolizumab with recommended or reduced starting doses of lenvatinib for treatment of recurrent endometrial cancer. Gynecol. Oncol. 2021, 162, 24-31. [CrossRef] [PubMed] 